$\mathcal{G}_{\text {doi: } 10.3765 / \text { sp.3.9 }}^{\text {Semantics \& Pragmatics Volume 3, Article 9: 1-74, } 2010}$

\title{
Cross-linguistic variation in modality systems: The role of $\operatorname{mood} *$
}

\author{
Lisa Matthewson \\ University of British Columbia
}

Received 2009-07-14 / First Decision 2009-08-20 / Revision Received 2010-02-01 / Accepted 2010-03-25 / Final Version Received 2010-05-31 / Published 2010-08-06

\begin{abstract}
The St'át'imcets (Lillooet Salish) subjunctive mood appears in nine distinct environments, with a range of semantic effects, including weakening an imperative to a polite request, turning a question into an uncertainty statement, and creating an ignorance free relative. The St'át'imcets subjunctive also differs from Indo-European subjunctives in that it is not selected by attitude verbs. In this paper I account for the St'át'imcets subjunctive using Portner's (1997) proposal that moods restrict the conversational background of a governing modal. I argue that the St'át'imcets subjunctive restricts the conversational background of a governing modal, but in a way which obligatorily weakens the modal's force. This obligatory modal weakening - not found with Indo-European non-indicative moods - correlates with the fact that St'át'imcets modals differ from Indo-European modals along the same dimension. While Indo-European modals typically lexically encode quantificational force, but leave conversational background to context, St'át'imcets modals encode conversational background, but leave quantificational force to context (Matthewson, Rullmann \& Davis 2007, Rullmann, Matthewson \& Davis 2008).
\end{abstract}

Keywords: Subjunctive, mood, irrealis, modals, imperatives, evidentials, questions, free relatives, attitude verbs, Salish

* I am very grateful to St'át'imcets consultants Carl Alexander, Gertrude Ned, Laura Thevarge, Rose Agnes Whitley and the late Beverley Frank. Thanks to David Beaver, Henry Davis, Peter Jacobs, the members of the UBC Pragmatics Research Group (Patrick Littell, Meagan Louie, Scott Mackie, Tyler Peterson, Amélia Reis Silva, Hotze Rullmann and Ryan Waldie), three anonymous reviewers, and audiences at New York University, the University of British Columbia and the 44th International Conference on Salish and Neighbouring Languages for helpful feedback and discussion. Thanks to Tyler Peterson for helping prepare the manuscript for publication. This research is supported by SSHRC grants \#410-2005-0875 and \#410-2007-1046.

(C)2010 Lisa Matthewson

This is an open-access article distributed under the terms of a Creative Commons NonCommercial License (creativecommons.org/licenses/by-nc/3.o). 
Lisa Matthewson

\section{Introduction}

Many Indo-European languages possess both modals, lexical items which quantify over possible worlds, and subjunctive moods, agreement paradigms which usually require a licensing modal element. The contrast is illustrated for Italian in (1)-(2). (1) contains modal auxiliaries; (2) contains subjunctive mood agreement which is licensed by the matrix attitude verb.
a. deve essere nell' ufficio
must+3SG+PRES+IND be in.the office

'He must be in the office.' $\quad$ (Italian; Palmer 2006: 102)

b. puo essere nell' ufficio

may+3SG+PRES+IND be in.the office

'He may be in the office.'

(Italian; Palmer 2006: 102)

(2) dubito che impari

I.doubt that learn+3SG+PRES+SBJN

'I doubt that he's learning.'

(Italian; Palmer 2006: 117)

Previous work on the Salish language St'át'imcets (a.k.a. Lillooet; see Matthewson et al. 2007, Rullmann et al. 2008, and Davis, Matthewson \& Rullmann 2009) has established the existence of a set of modals in this language, which differ in their semantics from those of Indo-European. Indo-European modals typically lexically encode distinctions of quantificational force, but leave conversational background (in the sense of Kratzer 1981, 1991) up to context. (1a), for example, unambiguously expresses necessity, while (1b) unambiguously expresses possibility. However, both modals allow either epistemic or deontic interpretations, depending on context. In contrast, modals in St'át'imcets lexically encode conversational background, but leave quantificational force up to context. (3a), for example, is unambiguously epistemic, but is compatible with either a necessity or a possibility interpretation, depending on context. (3b) is unambiguously deontic, but similarly allows differing quantificational strengths. See Matthewson et al. 2007, Rullmann et al. 2008, and Davis et al. 2009 for extensive discussion. ${ }^{1}$

1 All St'át'imcets data are from primary fieldwork unless otherwise noted. Data are presented in the practical orthography of the language developed by Jan van Eijk; see van Eijk \& Williams 1981. Abbreviations: ADHORT: adhortative, CAUS: causative, CIRC: circumstantial modal, COL: collective, COMP: complementizer, COND: conditional, cONJ: conjunctive, COUNTER: counter to expectations, DEIC: deictic, DEON: deontic, DEMON: demonstrative, DET: 
Cross-linguistic variation in modality systems: The role of mood

(3)
a. wá7=k'a s-t'al l=ti=tsítcw-s=a
be=EPIS STAT-stop in=DET=house-3SG.POSS=EXIS
$\mathrm{s}=$ Philomena
NOM=Philomena

'Philomena must / might be in her house.' ONLY EPISTEMIC

b. lán=lhkacw=ka áts'x-en ti=kwtámts-sw=a

already=2SG.SUBJ=DEON see-DIR DET=husband-2SG.POSS=EXIS

'You must / can / may see your husband now.' ONLY DEONTIC

A simplified table representing the difference between the two types of modal system is given in Table 1 :

\begin{tabular}{|c|c|c|}
\hline & $\begin{array}{l}\text { QUANTIFICATIONAL } \\
\text { FORCE }\end{array}$ & $\begin{array}{l}\text { CONVERSATIONAL } \\
\text { BACKGROUND }\end{array}$ \\
\hline $\begin{array}{l}\text { Indo-European } \\
\text { St'át'imcets }\end{array}$ & $\begin{array}{l}\text { lexical } \\
\text { context }\end{array}$ & $\begin{array}{l}\text { context } \\
\text { lexical }\end{array}$ \\
\hline
\end{tabular}

Table 1 Indo-European vs. St'át'imcets modal systems

In this paper I extend the cross-linguistic comparison to the realm of mood. I argue that St'át'imcets possesses a subjunctive mood, and show that it induces a range of apparently disparate semantic effects, depending on the construction in which it appears. One example of the use of the subjunctive is given in (4): it weakens the force of a deontic modal proposition (in a sense to be made precise below). Other uses include turning imperatives into polite requests, and turning questions into statements of uncertainty (cf. van Eijk 1997 and Davis 2006).

$$
\begin{aligned}
& \text { a. } \text { gúy't=Ø=ka ti=sk'úlk'wm'it=a } \\
& \text { sleep=3INDIC=DEON DET=child=EXIS } \\
& \text { 'The child should sleep.' }
\end{aligned}
$$

determiner, DIR: directive transitivizer, DS: different subject, EPIS: epistemic, ERG: ergative, EXIS: assertion of existence, FOC: focus, FUT: future, IMPF: imperfective, INCH: inchoative, INDIC: indicative, INFER: inferential evidential, IRR: irrealis, LOC: locative, MID: middle intransitive, NOM: nominalizer, OBJ: object, PRT: particle, PASS: passive, PERC.EVID: perceived evidence, PL: plural, POSS: possessive, PREP: preposition, REAL: realis, RED: redirective applicative, REM.PAST: remote past, SBJN: subjunctive, SG: singular, SIM: simultaneous, STAT: stative, TEMP.DEIC: temporal deictic, YNQ: yes-no question. The symbol - marks an affix boundary and $=$ marks a clitic boundary. 
b. guy't=ás=ka ti=sk'úk'wm'it=a

sleep $=\mathbf{3 S B J N}=$ DEON DET $=$ child $=$ EXIS

'I hope the child sleeps.'

I will show that the St'át'imcets subjunctive differs markedly from IndoEuropean subjunctives, both in the environments in which it is licensed, and in its semantic effects. I propose an analysis of the St'át'imcets subjunctive which adopts insights put forward by Portner (1997, 2003). For Portner, moods in various Indo-European languages place restrictions on the conversational background of a governing modal. I argue that the St'át'imcets subjunctive mood can be analyzed within exactly this framework, with the twist that in St'át'imcets, the restriction the subjunctive places on the governing modal obligatorily weakens the force of the proposition expressed.

This has an interesting consequence. While we can account for the St'át'imcets subjunctive using the same theoretical tools as for Indo-European, at a functional level the two languages are using their mood systems to achieve quite different effects. In particular, St'át'imcets uses its mood system to restrict modal force - precisely what this language does not restrict via its lexical modals. At a functional level, then, we find the same kind of cross-linguistic variation in the domain of mood as we do with modals. This idea is illustrated in the simplified typology in Table 2:

\begin{tabular}{lll} 
& $\begin{array}{l}\text { LEXICALLY RESTRICT } \\
\text { QUANT. FORCE }\end{array}$ & $\begin{array}{l}\text { LEXICALLY RESTRICT } \\
\text { CONVERS. BACKGROUND }\end{array}$ \\
\hline $\begin{array}{l}\text { Indo-European } \\
\text { St'át'imcets }\end{array}$ & $\begin{array}{l}\text { modals } \\
\text { moods }\end{array}$ & $\begin{array}{l}\text { moods } \\
\text { modals }\end{array}$
\end{tabular}

Table 2 Modal and mood systems

These results suggest that while individual items in the realm of mood and modality lexically encode different aspects of meaning, the systems as a whole have very similar expressive power.

The structure of the paper: Section 2 introduces the St'át'imcets subjunctive data. I first illustrate the nine different uses of the relevant agreement paradigm, and then argue that this agreement paradigm is a subjunctive, rather than an irrealis mood. Section 3 shows that the St'át'imcets subjunctive is not amenable to existing analyses of more familiar languages. 
Cross-linguistic variation in modality systems: The role of mood

Section 4 reviews the basic framework adopted, that of Portner (1997), and Section 5 provides initial arguments for adopting a Portner-style approach for St'át'imcets. Section 6 presents the formal analysis, and Section 7 applies the analysis to a range of uses of the subjunctive. Section 8 concludes and raises some issues for future research.

\section{St'át'imcets subjunctive data}

St'át'imcets possesses a complex system of subject and object agreement. There are different subject agreement paradigms for transitive vs. intransitive predicates. For intransitive predicates, there are three distinct subject paradigms, one of which is glossed as 'subjunctive' by van Eijk (1997) and Davis (2006). ${ }^{2}$

\begin{tabular}{|c|c|c|c|}
\hline & \multicolumn{2}{|c|}{ INDICATIVE } & \multirow[t]{2}{*}{ SUBJUNCTIVE } \\
\hline & INDICATIVE & NOMINALIZED & \\
\hline 1SG & tsút=kan & $\mathbf{n}=\mathrm{s}=\mathrm{tsut}$ & tsút=an \\
\hline $2 S G$ & tsút=kacw & $s=t s u ́ t=s u$ & tsút=acw \\
\hline 3SG & tsut $=\varnothing$ & $\mathrm{s}=\mathrm{tsú} \mathrm{t}=\mathbf{s}$ & tsút=as \\
\hline $1 P L$ & tsút=kalh & $\mathrm{s}=\mathrm{tsút}=\mathbf{k a l h}$ & tsút=at \\
\hline $2 \mathrm{PL}$ & tsút=kal’ap & $\mathrm{s}=\mathrm{tsút} \mathrm{t}=\mathrm{lap}$ & tsút=al'ap \\
\hline $3 P L$ & tsút=wit & $\mathrm{s}=\mathrm{tsút}=\mathbf{i}$ & tsút=wit=as \\
\hline
\end{tabular}

Table 3 Subject agreement paradigms for the intransitive predicate tsut 'to say' (adapted from van Eijk 1997: 146)

With transitive predicates, the situation is similar, except that there are four separate paradigms, one of which is subjunctive..$^{3,4}$

2 The cognate forms are often called 'conjunctive' in other Salish languages, primarily in order to disambiguate the abbreviations for 'subject' and 'subjunctive'. See for example Kroeber 1999.

3 The traditional terms for the first two columns are 'indicative' and 'nominalized' respectively. The nominalized endings are identical to nominal possessive endings, and are glossed as 'Poss' in the data. The choice between these first two paradigms is syntactically governed: the so-called 'indicative' surfaces in matrix clauses and relative clauses, while the nominalized paradigm appears in subordinate clauses. Both these sets contrast semantically, in all syntactic environments, with the subjunctive, hence my overall categorization of the first two paradigms as 'indicative'.

4 See Kroeber 1999 and Davis 2000 for justification of the analysis of subject inflection 
In subsection 2.1 I illustrate the uses of the paradigms glossed as subjunctive, and in subsection 2.2 I argue that these paradigms more closely approximate familiar subjunctives, rather than irrealis moods.

\subsection{Uses of the St'át'imcets subjunctive}

The mood I am glossing as 'subjunctive' has a wide range of uses, which at first glance are not easily unifiable. I illustrate all of them here. First, the subjunctive functions to turns a plain assertion into a wish (Davis 2006: chapter 24). ${ }^{5}$
a. nilh s=Lémya7 ti=kél $7=a$
FOC NOM=Lémya7 DET=first=EXIS
'Lémya7 is first.'
b. nílh=as s=Lémya7 ku=kéla7
FOC $=3$ SBJN NOM=Lémya7 DET=first

'May Lémya7 be first.'

(6)
a. ámh=as ku=scwétpcen-su!
good=3SBJN DET=birthday=2SG.POSS
'May your birthday be good!'
b. ámh=as $\mathrm{ku}=\mathrm{s}=$ wá7 $=\mathrm{su}$ !
good=3SBJN DET=NOM=be=2SG.POSS
'Best wishes!' ['May your being be good.'] (Davis 2006: ch. 24)

This use of the subjunctive is very restricted (see van Eijk 1997: 147). Minimal pairs cannot usually be constructed for ordinary assertions, as shown in (7)-(9).
(7)
a. kwis lhkúnsa
rain today
'It's raining today.'
rain $=\mathbf{3 S B J N}$ today
intended: 'May it rain today.'
b. *kwís=as lhkúnsa

assumed here. I do not provide the transitive paradigms, as subject markers vary based on the person and number of the object and the table is excessively large. See van Eijk 1997 and Davis 2006 for details.

5 The determiner alternation between ( $5 a)$ and (5b) $(t i=\ldots=a$ vs. $k u=)$ is predictable, but irrelevant for current concerns. See Matthewson 1998, 1999 for discussion. 
Cross-linguistic variation in modality systems: The role of mood

$$
\begin{aligned}
& \text { a. áma ti=sq'ít=a } \\
& \text { good DET=day=EXIS } \\
& \text { 'It is a good day.' } \\
& \text { b. *ámh=as ti=sq'ít=a } \\
& \text { good=3SBJN DET=day=EXIS }
\end{aligned}
$$

intended: 'May it be a good day.'

(9) a. guy't ti=sk'úk'wm'ita

sleep DET=child=EXIS

'The child is sleeping.'

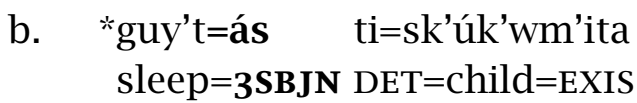

intended: 'I hope the child sleeps.'

In general, the subjunctive seems only to add to a plain assertion either in a cleft structure, as in (5), or in conventionalized wishes, as in (6). I return to this issue below.

The more usual case of the subjunctive creating a wish-statement is when it co-occurs with the deontic modal $k a$, as in (10)-(11).
a. $\quad$ plan=ka=tí $=$ t'u 7
wa7 máys-n-as

already $=$ DEON=DEMON=PRT IMPF fix-DIR-3ERG

'He should have fixed that already.'
b. plan=as=ká=tí7=t'u7 wa7 máys-n-as
already $=\mathbf{3 S B J}=\mathbf{N}=\mathbf{D E O N}=$ DEMON=PRT IMPF fix-DIR-3ERG
'I wish he had fixed that already.'
a. gúy’t=ka ti=sk'úk'wm'it=a
sleep $=$ DEON DET=child $=$ EXIS
'The child should sleep.'
b. gúy't=ás=ka ti=sk'úk'wm'it=a
sleep $=\mathbf{3 S B J N}=\mathbf{D E O N}$ DET $=$ child $=$ EXIS
'I hope the child sleeps.'

When used with the deontic modal $k a$, in addition to the 'wish' interpretation shown in (10)-(11), the subjunctive can also render a 'pretend to be ...' interpretation. ${ }^{6}$

6 The data in (12) are from the Upper St'át'imcets dialect; in Lower St'át'imcets, (12a) is corrected to (i), which has the subjunctive but lacks the deontic modal. This independent 
a. skalúl7=acw=ka: saq'w knáti7 múta7 em7ímn-em owl=2SG.SBJN=DEON fly DEIC and animal.noise-MID 'Pretend to be an owl: fly around and hoot.'

(Davis 2006: chapter 24)

b. snu=hás=ka ku=skícza7

2SG.EMPH=3SBJN=DEON DET=mother

'Pretend to be the mother.'

(Whitley, Davis, Matthewson \& Frank (editors) no date)

The fourth construction which licenses the subjunctive is the imperative; the subjunctive weakens an imperative to a polite request (Davis 2006: chapter 24). In each of (13)-(15), the subjunctive imperative in (b) is construed as 'more polite' than the plain imperative in (a). The subjunctive is particularly common in negative requests, as in (15).
a. lts7á=malh lh=kits-in'=ál'ap!
DEIC $=$ ADHORT $C O M P=$ put.down-DIR=2PL.SBJN
'Just put it over here!'
b. lts7á=has=malh lh=kits-in'=ál'ap
DEIC $=3$ SBJN $=$ ADHORT COMP $=$ put.down-DIR $=2$ PL.SBJN

'Could you put it down here?'/'You may as well put it down over here.'7
a. nás=malh áku7 pankúph=a
go=ADHORT DEIC Vancouver=EXIS
'You'd better go to Vancouver.'
b. nás=acw=malh áku7 pankúph=a
go=2SG.SBJN=ADHORT DEIC Vancouver=EXIS
'You could go to Vancouver.'

pronoun construction is argued by Thoma (2007) to be a concealed cleft. I return to this issue below.

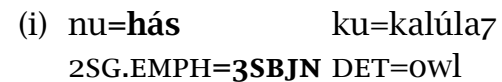

'Pretend to be an owl.'

7 The third person subjunctive ending appears here because the structure is bi-clausal, involving a third-person impersonal main predicate: 'It is here that you could put it down.' 
Cross-linguistic variation in modality systems: The role of mood
a. cw7aoz $\mathrm{kw}=\mathrm{s}=$ sek'w-en-ácw
ta=nk'wanústen'=a
NEG
$\mathrm{DET}=\mathrm{NOM}=$ break-DI
DET=window=EXIS
'Don't break the window.'
b. cw7áoz=as $\mathrm{kw}=\mathrm{s}=\mathrm{sek}^{\prime} w$-en-ácw ta=nk'wanústen'=a
$\mathrm{NEG}=$ 3SBJN DET $=$ NOM=break-DIR-2SG.ERG DET=window $=$ EXIS

'Don't break the window.'

Fifth, in combination with an evidential or a future modal, the subjunctive helps to turn wh-questions into statements of uncertainty or wondering.
a. kanem=lhkán=k'a
do.what=1SG.INDIC $=$ INFER
'What happened to me?'
b. kanem=án=k’a
do.what=1SG.SBJN=INFER

'I don't know what happened to me.' / 'I wonder what I'm doing.'

(17) a. kanem=lhkácw=kelh múta7

do.what=2SG.INDIC $=$ FUT again

'What are you going to be doing later?'
b. kanem=ácw=kelh múta7
do.what=2SG.SBJN=FUT again

'I wonder what you are going to do again.' (van Eijk 1997: 215)
a. nká7=kelh $l h=c u ́ z=a c w \quad$ nas
where $=$ FUT COMP $=$ going.to $=2$ SG.SBJN go
'Where will you go?'
b. nká $7=$ as $=$ kelh $\quad l h=$ cú $^{\prime}=\mathrm{acw}$ nas
where $=\mathbf{3 S B J N}=$ FUT $\mathbf{C O M P}=$ going.to $=2$ SG.SBJN go
'Wherever will you go?' / 'I wonder where you are going to go now.' (adapted from Davis 2006: chapter 24)

The same effect arises with yes-no questions. In combination with the evidential $k^{\prime} a$ or a future modal, the subjunctive also turns these into statements of uncertainty which are often translated using 'maybe' or 'I wonder'.

8 For expository reasons, $k$ 'a was glossed as 'epistemic' in (за) above, but from now on will be glossed as 'inferential'. Matthewson et al. (2007) analyze $k$ ' $a$ as an epistemic modal which carries a presupposition that there is inferential evidence for the claim. 
(19) a. lán=ha kwán-ens-as

already=YNQ take-DIR-3ERG

ni=n-s-mets-cál=a

DET.ABS=1SG.POSS-NOM-write-ACT=EXIS

'Has she already got my letter?'

b. lan=as=há=k’a kwán-ens-as

already $=\mathbf{3 S B J N}=\mathbf{Y N Q}=\mathbf{I N F E R}$ take-DIR-3ERG

ni=n-s-mets-cál=a

DET.ABS=1SG.POSS-NOM-write-ACT=EXIS

'I wonder if she's already got my letter.'/'I don't know if she got my letter or not.'

(20) wa7=as=há=k’a tsicw

$\mathrm{IMPF}=\mathbf{3 S B J N}=\mathbf{Y N Q}=\mathbf{I N F E R}$ get.there

$\mathrm{i}=\mathrm{n}$-sésq'wez' $=\mathrm{a}, \quad$ cw7aoz $\mathrm{kw}=\mathrm{en}$

DET.PL=1SG.POSS-younger.sibling=EXIS NEG DET=1SG.POSS

zwát-en

know-DIR

'Perhaps my younger siblings went along, I don't know.'

(Matthewson 2005: 265)

In combination with a $w h$-indefinite and the evidential $k$ ' $a$, the subjunctive creates free relatives with an 'ignorance/free choice' reading; see Davis 2006 for discussion.

(21) a. qwatsáts=t'u7 múta7 súxwast áku7, t’ak aylh áku7,

leave=PRT again go.downhill DEIC go then DEIC

nílh=k’a $\quad$ s=npzán-as

FOC=INFER NOM=meet(DIR)-3ERG

k'a=lh=swát=as=k'a kátiz ku=npzán-as

INFER $=$ COMP $=$ who=3SBJN=INFER DEIC DET=meet(DIR)-3ERG

'So he set off downhill again, went down, and then he met whoever he met.' (van Eijk \& Williams 1981: 66, cited in Davis 2009)

b. o, púpen'=lhkan [ta=stam'=as=á=k'a]

oh find $=1$ SG.INDIC $[$ DET $=$ what $=3$ SBJN=EXIS $=$ INFER $]$

'Oh, I've found something or other.'

(Unpublished story by "Bill” Edwards, cited in Davis 2009)

When used in combination with the scalar particle $t$ ' $u$, the subjunctive creates a statement translated as 'might as well' or 'may as well'. 
Cross-linguistic variation in modality systems: The role of mood

a. wá7=lhkan=t'u7 wa7 k'wzús-em

IMPF $=1$ SG.INDIC $=$ PRT IMPF work-MID

'I am just working.'

b. wá7=an=t'u7 wa7 k'wzús-em

IMPF $=$ 1SG.SBJN=PRT IMPF work-MID

'I might as well stay and work.'

(23) a. wá7=lhkacw=t'u7 lts7a lhkúnsa ku=sgáp

be=2SG.INDIC=PRT DEIC now DET=evening

'You are staying here for the night.'

b. wá7=acw=t'u7 lts7a lhkúnsa ku=sgáp

be=2SG.SBJN=PRT DEIC now DET=evening

'You may as well stay here for the night.'

And finally, in combination with a wh-word and the scalar particle t'u7, the subjunctive creates free relatives with a universal / indifference reading.

a. wa7 táw-em ki=smán'c=a, ns7á7z'-em

IMPF sell-MID DET.COL=tobacco=EXIS trade-MID

$\mathrm{ku}=\mathbf{s t a ́ m}$ '=as=t'u 7

DET $=$ what $=3$ SBJN $=$ PRT

'He was selling tobacco, trading it for whatever ...'

(van Eijk \& Williams 1981: 74, cited in Davis 2009)

b. wa7 kwám=wit ku=káopi, ku=súkwa, ku=saplín, IMPF take(MID)=3PL DET=coffee DET=sugar DET=flour

[stám'=as=t'u7 cw7aoz

[what $=3$ SBJN $=$ PRT NEG

$\mathrm{kw}=\mathrm{s}=\mathrm{ka}$-ríp-s-tum'-a

DET $=$ NOM=CIRC-grow-CAUS-1PL.ERG-CIRC

$\mathrm{l}=\mathrm{ti}=$ tmícw-lhkalh=a]

on $=$ DET $=$ land -1 PL.POSS $=$ EXIS]

'They got coffee, sugar, flour, whatever we couldn't grow on our land...'

(Matthewson 2005: 105, cited in Davis 2009)

c. [stám'=as=t'u7 káti7 i=wá7

[what $=3$ SBJN $=$ PRT DEIC DET.PL $=$ IMPF

ka-k'ac-s-twítas-a $\quad \mathrm{i}=$ n-slalíl'tem=a]

CIRC-dry-CAUS-3PL.ERG-CIRC DET.PL=1SG.POSS-parents=EXIS]

wa7 ts'áqw-an'-em lh=as sútik

IMPF eat-DIR-1PL.ERG COMP(IMPF) $=3$ SBJN winter 
'Whatever my parents could dry, we ate in wintertime.'

(Matthewson 2005: 141, cited in Davis 2009)

The nine uses of the St'át'imcets subjunctive are summarized in Table 4:

\begin{tabular}{|c|c|c|}
\hline ENVIRONMENT & INDICATIVE MEANING & SUBJUNCTIVE MEANING \\
\hline plain assertion & assertion & wish \\
\hline deontic modal & deontic necessity/possibility & wish \\
\hline deontic modal & deontic necessity/possibility & 'pretend' \\
\hline imperative & command & polite request \\
\hline $\begin{array}{l}\text { wh-question + } \\
\text { evidential/future }\end{array}$ & question & uncertainty/wondering \\
\hline $\begin{array}{l}\text { yes-no question + } \\
\text { evidential/future }\end{array}$ & question & uncertainty/wondering \\
\hline wh-word + evidential & question & ignorance free relative \\
\hline scalar particle t'u & ‘just/still’ & 'might as well' \\
\hline $\begin{array}{l}\text { wh-word + scalar } \\
\text { particle t'u7 }\end{array}$ & $\mathrm{N} / \mathrm{A}$ & indifference free relative \\
\hline
\end{tabular}

Table 4 Uses of the St'át'imcets subjunctive

These are all the cases where the subjunctive has a semantic effect; in the next sub-section we will also see some cases where the subjunctive is obligatory and semantically redundant. I will not aim to account for the entire panoply of subjunctive effects in one paper. However, the analysis I offer will explain the first seven uses, setting aside for future research only the two uses which involve the particle t'u7. See Section 8 for some speculative comments about the subjunctive in combination with t'u7.

\subsection{This is a subjunctive mood}

In this sub-section I justify the use of the term 'subjunctive' for the subject agreements being investigated. The choice of terminology is intended to reflect the fact that the St'át'imcets mood patterns with Indo-European subjunctives, rather than with Amerindian irrealis moods, in several respects. However, we will see below that the St'át'imcets subjunctive also differs 
Cross-linguistic variation in modality systems: The role of mood

semantically in important ways from Indo-European subjunctives. ${ }^{9}$

Palmer (2006) observes that there is a broad geographical typology, such that European languages often encode an indicative/subjunctive distinction, while Amerindian and Papuan languages often encode a realis/irrealis distinction. A typical irrealis-marking system is illustrated in (25).

a. ho bu-busal-en age qo-in

pig SIM-run.out-3SG+DS+REAL 3PL hit-3PL+REM.PAST

'They killed the pig as it ran out.' (Amele; Palmer 2006: 5)

b. ho bu-busal-eb age qo-qag-an

pig SIM-run.out-3SG+DS+IRR 3PL hit-3PL-FUT

'They will kill the pig as it runs out.' (Amele; Palmer 2006: 5)

According to Palmer (2006: 145), the indicative/subjunctive distinction and the realis/irrealis distinction are 'basically the same'. The core function of both a subjunctive and an irrealis is to encode 'non-assertion'. ${ }^{10}$ However, there are differences in distribution and in syntactic functions.

First, Palmer observes that subjunctive is not marked independently of other inflectional categories such as person and number. Instead, there is typically a full subjunctive paradigm. On the other hand, irrealis is often marked by a single element. In this respect, the St'át'imcets mood patterns like a subjunctive; see Table 3 above.

Second, in main clauses, irrealis marking is often used for questions, futures and denials; this is not the case for main clause subjunctives. In this respect also, the St'át'imcets mood patterns like a subjunctive. It is not used to mark questions, futures or denials. (26)-(28) all have indicative marking.

9 This raises a terminological issue which arises in many areas of grammar. Should we apply terms which were invented for European languages to similar - but not identical - categories in other languages? For example, should we say 'The perfect / definite determiner / subjunctive in language $X$ differs semantically from its English counterpart', or should we say 'Language $X$ lacks a perfect / definite determiner / subjunctive', because it lacks an element with the exact semantics of the English categories? I adopt the former approach here, as I think it leads to productive cross-linguistic comparison, and because it suggests that the traditional terms do not represent primitive sets of properties, but rather potentially decomposable ones.

10 Palmer does not provide a definition of 'non-assertion'. He observes that common reasons why a proposition is not asserted are because the speaker doubts its veracity, because the proposition is unrealized, or because it is presupposed (Palmer 2006: 3). See Section 3 below for discussion. 
t'íq $=\varnothing=$ ha $\quad \mathrm{kw}=\mathrm{s}=\mathrm{Josie} ?$

arrive $=$ 3INDIC $=$ YNQ DET $=$ NOM $=$ Josie

'Did Josie arrive?'

(27) t'íq= $\varnothing=$ kelh $\quad \mathrm{kw}=\mathrm{S}=\mathrm{Josie}$

arrive $=\mathbf{3}$ INDIC $=$ FUT DET $=$ NOM $=$ Josie

'Josie will arrive.'

$$
\begin{array}{lll}
\text { cw7aoz } & \mathrm{kW}=\mathrm{s}=\mathrm{t}^{\prime} \mathrm{iq}=\mathbf{s} & \mathrm{s}=\mathrm{Josie} \\
\text { NEG } & \mathrm{DET}=\mathrm{NOM}=\text { arrive=3POSS } & \text { NOM=Josie }
\end{array}
$$

'Josie didn’t arrive.'

Third, Palmer notes that subjunctive marking is obligatory and redundant only in subordinate clauses, while irrealis marking is often obligatory and redundant in main clauses. Here again, the St'át'imcets mood patterns like a subjunctive. It is obligatory and redundant only in three cases. The first is when embedded under the complementizer $l h=. l h=$ is glossed by van Eijk (1997) as 'hypothetical', and analyzed by Davis (2006) as a complementizer which introduces subjunctive clauses, including if-clauses, as in (29a) and (29b), temporal adjuncts (29b), locative adjuncts (29c), and complements to the evidential $k^{\prime} a$ when this is used as a (focused) adverb (29d).

(29) a. lh=cw7áoz $*=$ as $)=\mathrm{ka} \quad \mathrm{kw}=\mathrm{s}=\mathrm{gú} \mathbf{y}^{\prime} \mathrm{t}=\mathrm{su}$, $\mathbf{C O M P}=\mathrm{NEG}^{*}(=\mathbf{3 S B J N})=$ IRR DET $=\mathrm{NOM}=$ sleep $=2$ SG.POSS

lán=ka=tu7 wa7 xzum i=n'wt'ústen-sw=a already=IRR=then IMPF big DET.PL=eye-2SG.POSS=EXIS

'If you hadn't slept, your eyes would have been big already.'

(van Eijk \& Williams 1981: 12)

b. $\quad \mathrm{xwáyt}=$ wit $=\mathrm{ka} \quad \mathbf{l h}=$ wa7=wit*(=ás)=t'u7 $\quad$ qyax many.people.die $=3 \mathrm{PL}=\mathrm{IRR} \mathbf{C O M P}=\mathrm{be}=3 \mathrm{PL} *(=3 \mathrm{SBJN})=\mathrm{PRT}$ drunk múta7 tqálk'-em $\mathbf{l h}=\mathrm{W}^{*}(=\mathbf{a s}) \quad$ qyáx=wit and drive-MID COMP $=\mathrm{IMPF}^{*}(=3 \mathbf{S B J N})$ drunk $=3 \mathrm{PL}$

'They would die if they got drunk and drove when they were drunk.'

(Matthewson 2005: 367)

c. lts7a lh=wa7*(=as) qwál'qwel't

DEIC COMP $=\mathrm{IMPF}^{*}(=3 \mathrm{SBJN})$ hurt

'It is here that it is hurting.' 
Cross-linguistic variation in modality systems: The role of mood

d. k’a lh=7án'was*(=as) sq'it,

maybe $\mathbf{C O M P}=$ two $^{*}(=\mathbf{3 S B J N})$ day

ka-láx-s-as-a n-skícez7=a

CIRC-remember-CAUS-3ERG-CIRC 1SG.POSS-mother=EXIS

na $=$ s-7ílacw-em-s=a

DET $=$ NOM-soak-MID-3POSS $=$ EXIS

ta=n-qéqtsek $=\mathrm{a}$

DET $=$ 1SG.POSS-older.brother $=$ EXIS

'Maybe two days later, my mother remembered the fish my brother had been soaking.'

(Matthewson 2005: 152; cited in Davis 2006: chapter 23) $)^{11}$

The second case where the St'át'imcets subjunctive is obligatory and redundant is when embedded under the complementizer $i=$ 'when', as in (30). $i=$ has a similar distribution to $l h=$, but is restricted to past-time contexts. See van Eijk 1997: 235-6 and Davis 2006: chapter 27 for discussion.
a. $\quad \mathbf{i}=$ kél7 =at
tsicw, áts'x-en-em
when.PAST=first=1PL.SBJN get.there see-DIR-1PL.ERG
$\mathrm{i}=\mathrm{cW}$ 7ít $=\mathrm{a} \quad$ tsitcw
DET $=$ many $=$ EXIS house
'When we first got there, we saw lots of houses.'

(Matthewson 2005: 74)
b. wá7=lhkan lexláx-s i=kwís*(=as)
$\mathrm{IMPF}=1$ SG.INDIC remember-CAUS when.PAST $=$ fall $*(=3 \mathbf{S B J N})$
na $=$ n-sésq'wez' $=\mathrm{a}$, $\quad \mathrm{s}=$ Harold $\quad$ Peter
DET.ABS=1SG.POSS-younger.sibling=EXIS NOM=Harold Peter

'I remember when my little brother was born, Harold Peter.'

(Matthewson 2005: 354-5)

11 Incidentally, Davis (2006: chapter 23) observes that 'two or more $k$ 'a $l h=$ clauses strung together form the closest equivalent in [St'át'imcets] of [English] "either...or".' An example is given in (i).

(i) k'a lh=xw7utsin-qín'=as, $\quad$ k'a $\quad \mathbf{l h}=$ =tsilkst-qín'=as=kelh maybe $\operatorname{comP}=$ four - animal $=3$ SBJN maybe $\operatorname{comP}=$ five-animal $=3$ SBJN $=F U T$

'It'll either be a four point or a five point buck.'

(Davis 2006: chapter 23) As Davis implies, St'át'imcets lacks any lexical item which renders logical disjunction, and constructions like (i), although used to translate English 'or', are literally two 'maybe'-clauses strung together. 
Finally, the subjunctive is obligatory when it appears in combination with the perceived-evidence evidential $=a n^{\prime}$. $=a n^{\prime}$ is analyzed by Matthewson et al. (2007) as an epistemic modal which is defined only if the speaker has perceived indirect evidence for the prejacent proposition.

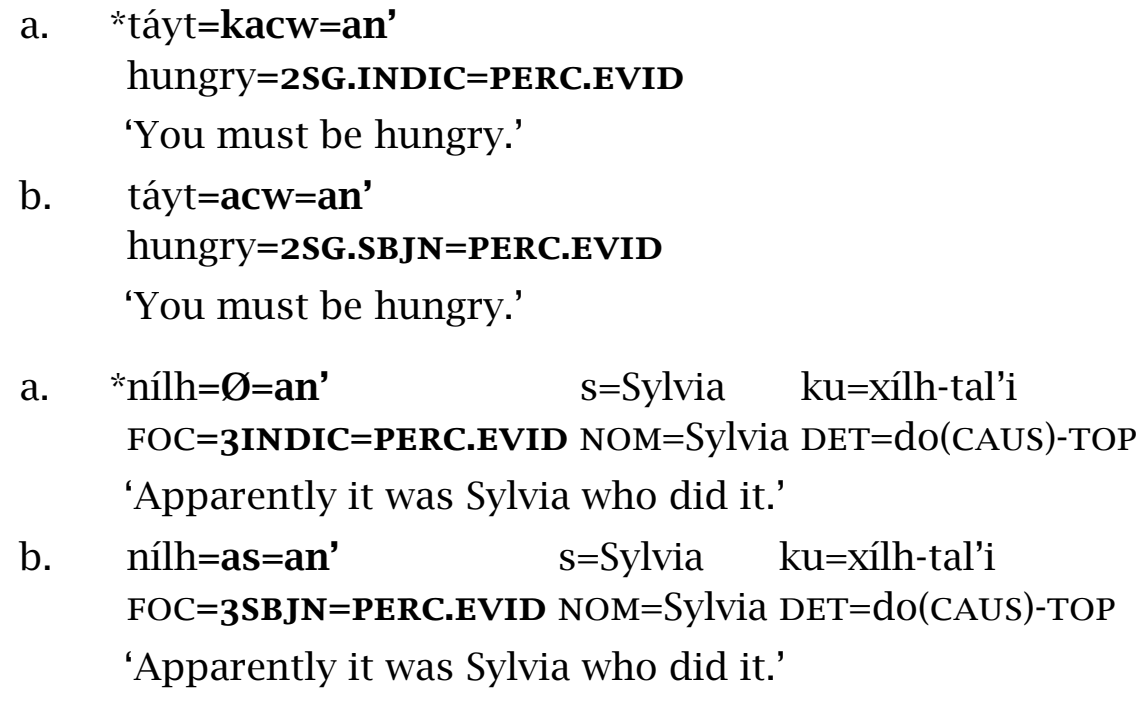

a. $\quad$ *nílh=Ø=an' $\quad$ s=Sylvia $\quad$ ku=xílh-tal'i
FOC=3INDIC=PERC.EVID NOM=Sylvia $\quad$ DET=do(CAUS)-TOP

'Apparently it was Sylvia who did it.'
b. nílh=as=an' $\quad s=$ Sylvia ku=xílh-tal'i FOC $=\mathbf{3 S B J N}=$ PERC.EVID NOM=Sylvia DET=do(CAUS)-TOP 'Apparently it was Sylvia who did it.'

(Matthewson et al. 2007: 208)

The perceived-evidence evidential is the only environment in the language where the subjunctive is obligatory in a matrix clause. I assume that the subjunctive lacks semantic import here, as an otherwise very similar evidential lákw7a does not allow the subjunctive in cases parallel to (31)-(32) (Matthewson 2010, to appear).

The conclusion is that St'át'imcets, in spite of being an Amerindian language, has a mood which patterns, at least morpho-syntactically, like a subjunctive rather than an irrealis. This fits with how van Eijk (1997) and Davis (2000, 2006) gloss the relevant forms. However, we will see in the next section that the St'át'imcets subjunctive differs semantically in interesting ways from European subjunctives.

\section{Why previous analyses do not work for St'át'imcets}

The vast majority of formal research on the subjunctive deals with IndoEuropean. In languages such as the Romance languages, the subjunctive mood is used for wishes, fears, speculations, doubts, obligations, reports, unrealized events, or presupposed propositions. Some examples are provided in (33)-(34). 
Cross-linguistic variation in modality systems: The role of mood

a. creo que aprende I.believe that learn+3SG+PRES+INDIC

'I believe that he is learning.'

(Spanish; Palmer 2006: 5)

b. dudo que aprenda

I.doubt that learn+3SG+PRES+SBJN

'I doubt that he's learning.'

(Spanish; Palmer 2006: 5)

(34)

potessi venire anch' io
can+1SG+PRES+SBJN come also I

'If only I could come too.'

(Italian; Palmer 2006: 109)

In this section I briefly discuss some of the main approaches to the subjunctive. I cannot do justice to the full array of proposals in the literature; the goal is to provide enough background to establish that the St'át'imcets subjunctive is not amenable to a range of existing approaches.

One pervasive line of thought is that subjunctive encodes a general semantic contribution of 'non-assertion' (Bolinger 1968, Terrell \& Hooper 1974, Hooper 1975, Klein 1975, Farkas 1992, Lunn 1995, Palmer 2006, Haverkate 2002, Panzeri 2003, among others). One recent formal proposal in this line is that of Farkas (2003). Farkas argues that there is a correlation between indicative mood and complements which have assertive context change potential relative to the embedded environment. Assertive context change for a matrix clause is defined as in (35); the context set of worlds $W_{c}$ is narrowed.

Assertive context change

$c+\phi$ is assertive iff $W_{c^{\prime}}=W_{c} \cap p$, where $c^{\prime}$ is the output context.

(Farkas 2003: 5)

Farkas provides an analysis of assertion in embedded contexts which predicts that positive epistemic predicates like believe or know take indicative complements, as these complements are asserted relative to the matrix subject's epistemic state. ${ }^{12}$

Predicates of assertion ('say', 'assert') and of fiction ('dream', 'imagine') similarly introduce complements which are assertively added to the embedded speech context, and also take indicative complements. On the other hand, complements to desideratives ('want', 'wish', 'desire') and directives ('command', 'direct', 'request') are not assertive. Rather than eliminating

12 Predicates like believe take subjunctive complements in Italian; see Giorgi \& Pianesi 1997, among many others, for discussion. 
worlds in the context set where the complement is false, these predicates eliminate worlds in the context set which are low on an evaluative ranking. ${ }^{13}$ Thus, these predicates take the subjunctive:

Maria vrea să-i răspundă

Maria wants SUBJ-CL answer.SBJN

'Maria wants to answer him.'

(Romanian; Farkas 2003: 2)

Giannakidou (1997, 1998, 2009) offers an alternative characterization of the distribution of the subjunctive, according to which it appears in nonveridical contexts, while indicative appears in veridical contexts. The relevant definition is given in (37):

(37) A propositional operator $F$ is veridical iff from the truth of $F p$ we can infer that $p$ is true relative to some individual $x$ (i.e., in some individual $x$ 's epistemic model) ... If inference to the truth of $p$ under $F$ is not possible, $F$ is nonveridical. $\quad$ (Giannakidou 2009: 1889)

According to this analysis, the division between indicative-taking and subjunctive-taking predicates relies on whether at least one epistemic agent is committed to the truth of the embedded proposition. Giannakidou's approach predicts a similar division between indicative- and subjunctivetaking predicates to Farkas's. In Modern Greek, the indicative is found in complements to predicates of assertion or fiction, epistemics, factives and semi-factives. The subjunctive is found in complements to volitionals, directives, modals, permissives, negatives, and verbs of fear (Giannakidou 2009: 9). ${ }^{14}$

An approach which aims to derive mood selection directly from the semantics of subordinating predicates is that of Villalta (2009). Villalta argues

13 The complements of desideratives are also not 'decided' relative to their context set, which is what is actually crucial here for Farkas (2003). Farkas proposes an Optimality Theory account involving the two constraints in (i):

(i) *SUBJ/+Decided *IND/-Assert

Different rankings of these two constraints give rise to different mood choices in Romanian vs. French for emotive factive predicates like 'be sorry/happy', 'regret'. Emotive factives are +Decided but -Assertive, and take the indicative in Romanian and the subjunctive in French.

14 Giannakidou (2009) proposes that the Modern Greek subjunctive complementizer na contributes temporal semantics (introducing a 'now' variable). The generalization is still that subjunctive appears in non-veridical contexts; see Giannakidou 2009 for details. 
Cross-linguistic variation in modality systems: The role of mood

that subjunctive-selecting predicates are those whose embedded propositions are compared to contextual alternatives on a scale encoded by the predicate. The contribution of the subjunctive is to evaluate the contextual alternatives.

Quer (1998, 2001), looking mainly at Catalan and Spanish, argues that the subjunctive signals a shift in the model of the evaluation of the truth of the proposition. For unembedded assertions, the anchor is the Speaker and the model is the epistemic model of the Speaker. Operators which introduce subjunctive introduce buletic models, or other models which create comparative relations among worlds. This predicts we will find subjunctive in purpose clauses, and predicts indicative/subjunctive alternations in restrictive relative clauses, concessives, and free relatives. Quer (2009) also discusses indicative/subjunctive alternations in conditionals, claiming that indicative appears in protases that are 'realistic in the sense that they quantify over worlds which are close enough to the actual one' (2009: 1780). Subjunctive is used when the worlds are further away from the actual one or even disjoint from it.

An approach to mood which draws on notions from noun phrase semantics is offered by Baker \& Travis (1997). Baker and Travis argue that in Mohawk, mood marks a division between 'verbal specificity' ('factive' mood) and Kamp/Heim-style indefiniteness (two variants of non-factive mood, previously called the 'future' and the 'optative'). Indefinite/non-factive mood appears in future contexts, in past habituals, in negative clauses, under the verbs 'promise' and 'want', and in free relatives with a non-specific reading. What links all these indefinite-mood environments, according to Baker and Travis, is the same feature that characterizes indefinite noun phrases in the Kamp/Heim system: a free variable (in the Mohawk case, an event variable) which undergoes existential closure in the scope of various operators.

This ends our brief tour through some major formal approaches to the subjunctive. ${ }^{15}$ The reader is referred to Portner (2003) for further overview and discussion. In the next sub-section I show that the St'át'imcets subjunctive does not behave like the Indo-European or Mohawk subjunctives, and that a new approach is required.

15 I defer discussion of Portner's (1997) analysis to Section 5, since I will be adapting Portner's approach for St'át'imcets. 


\subsection{The St'át'imcets subjunctive is not amenable to existing approaches}

The St'át'imcets subjunctive differs from familiar subjunctives in both its distribution and semantic effects. Although there are some initial similarities, such as the fact that both St'át'imcets and Indo-European subjunctives can be used to express wishes and hopes, St'át'imcets mood displays no sensitivity to the choice of matrix predicate. Thus, unlike in Romance or Greek, predicates of assertion, belief and fiction are not differentiated from desideratives or directives. All attitude verbs in St'át'imcets take the indicative, as illustrated for a representative range in (38). ${ }^{16,17}$

$$
\begin{aligned}
& \text { a. tsut } \mathrm{k}=\text { Laura } \mathrm{kw}=\mathrm{s}=\mathrm{t}^{\prime} \mathrm{iq}=\varnothing \quad \mathrm{k}=\mathrm{John} \\
& \text { say } \text { DET }=\text { Laura DET }=\text { NOM=arrive=3INDIC DET }=\text { John } \\
& \text { 'Laura said that John came.' } \\
& \text { b. tsut-ánwas } \mathrm{k}=\text { Laura } \quad \mathrm{kw}=\mathrm{s}=\mathrm{t}^{\prime} \mathrm{iq}=\varnothing \quad \mathrm{k}=\mathrm{John} \\
& \text { say-inside det=Laura DET }=\text { NOM=arrive=3INDIC DET }=\text { John } \\
& \text { 'Laura thought that John came.' } \\
& \text { c. zwát-en-as } \mathrm{k}=\text { Laura } \mathrm{kw}=\mathrm{s}=\mathrm{t}^{\prime} \mathrm{iq}=\varnothing \quad \mathrm{k}=\mathrm{John} \\
& \text { know-DIR-3ERG DET=Laura DET=NOM=arrive=3INDIC DET=John } \\
& \text { 'Laura knew that John came.' }
\end{aligned}
$$

16 Interestingly, the same is not true of the related language Skwxwú7mesh (Squamish). In Sk $\underline{\text { w }}$ wúfmesh, the subjunctive (glossed as 'conjunctive'; see fn. 2) is obligatory under 'tell someone to do something' (as in (i)), but is optional under 'I think', depending on whether the speaker knows that the event did not take place (ii-iii) (all data from Peter Jacobs, p.c.).

(i) chen tsu-n- $\varnothing-\varnothing \quad \mathrm{mi}$ as uys

I tell-DIR-DAT-3OBJ come 3CONJ come.inside

'I told him to come inside.'

(ii) chen ta7aw'n kwi s-Ø-s mi uys

I think det nom-real-3POss come come.inside

'I think he came inside.'

(iii) chen ta7aw'n $\underline{k}^{\prime}$-as mi uys

I think IRR-3CONJ come come.inside

'I thought he came inside (but then I found out that he's still outside playing).'

Jacobs (1992) analyzes the mood distinction in Skwxwú7mesh as encoding speaker certainty, which suggests that it differs from the St'át'imcets mood system.

17 The expected subject inflection in the embedded clauses in (38) would actually be possessive =s; see van Eijk 1997 and Davis 2006. However, many modern speakers prefer to omit the possessive ending and to use matrix indicative $=\varnothing$ in these contexts. This does not affect the point at hand, as the variation is between two forms of indicative marking. 
Cross-linguistic variation in modality systems: The role of mood
d.
kw7íkwl'acw k=Laura $\quad \mathrm{kw}=\mathrm{s}=\mathrm{t}$ 'iq $=\varnothing$
$\mathrm{k}=\mathrm{John}$
dream DET $=$ Laura DET $=$ NOM=leave $=3$ INDIC DET $=$ John
'Laura dreamt that John came.'
e. xát'-min'-as $\mathrm{k}=$ Laura $\mathrm{kw}=\mathrm{s}=\mathrm{t}$ 'iq=Ø $\mathrm{k}=\mathrm{John}$
want-RED-3ERG DET=Laura DET $=$ NOM=arrive $=3$ INDIC DET $=$ John
'Laura wanted John to come.'
f. tsa7cw $\mathrm{k}=$ Laura $\mathrm{kw}=\mathrm{s}=\mathrm{t}^{\prime} \mathrm{iq}=\varnothing \quad \mathrm{k}=\mathrm{John}$
glad $\quad$ DET $=$ Laura DET $=$ NOM=arrive $=3$ INDIC DET $=$ John
'Laura was happy that John came.'
g. tsún-as $\mathrm{k}=$ Laura $\mathrm{k}=\mathrm{John} \quad \mathrm{kw}=\mathrm{s}=\mathrm{ts}$ 7as $=\varnothing$
say(DIR)-3ERG DET=Laura DET $=$ John DET $=$ NOM=COMe $=3$ INDIC
'Laura told John to come.'18

The St'át'imcets subjunctive is also not used under negated verbs of belief or report, as it is in many European languages (cf. Palmer 2006: 116). Compare Spanish (39a) with St'át'imcets (39b) and (39c).
a. no creo que aprenda
not I.think that learn+3SG+PRES+SBJN
'I don't think that he is learning.' (Spanish; Palmer 2006: 117)
b. cw7aoz kw=en=tsut-ánwas $\quad \mathrm{kw}=\mathrm{s}=\mathrm{z}$ wátet-cal=s
NEG DET $=1$ SG.POSS $=$ say-inside DET $=$ NOM=know-ACT $=3$ POSS
'I don't think that he is learning.'
c. $\quad$ cw7aoz $\mathrm{kw}=\mathrm{s}=\mathrm{tsut}=\mathrm{s} \quad \mathrm{kw}=\mathrm{s}=$ Aggie
NEG $\quad$ DET $=$ NOM=say $=3$ POSS DET $=$ NOM=Aggie
$\mathrm{kW}=\mathrm{s}=\mathrm{t}$ 'cum $=\mathbf{S} \quad \mathrm{i}=$ gáp $=\mathrm{as}$
$\mathrm{DET}=\mathrm{NOM}=$ win $=3$ POSS when.PAST $=$ evening $=3 \mathrm{SBJN}$
'Aggie didn't say she won last night.'

Nor does the St'át'imcets subjunctive give rise to interpretive differences inside relative clauses. In some Indo-European languages, an indicative/subjunctive contrast in restrictive relatives gives rise to a distinction which has variously been analyzed as referential/attributive, specific/nonspecific, or wide-scope/narrow-scope (see Rivero 1975, Farkas 1992, Giannakidou 1997, Beghelli 1998, Quer 2001, among many others). This is illustrated in

18 The predicate in (38g) differs from that in (38a)-(38f) because the 'ordering' environment in $(38 \mathrm{~g})$ requires an unergative embedded verb. 
(40) for Catalan. Quer's analysis of these examples involves a shifting of the model in which the descriptive condition in the relative clause is interpreted; the effect is one of apparent 'wide-scope' for the descriptive condition in the indicative (40a), as opposed to in the subjunctive (4ob).

(40) a. necessiten un alcalde [que fa grans

need.3PL a mayor that make.INDIC.PRS.3SG big inversions]

investments

'They need a mayor that makes big investments.'

(Catalan; Quer 2001: 90)

b. necessiten un alcalde [que faci grans

need.3PL a mayor that make.SBJN.PRS.3SG big inversions]

investments

'They need a mayor that makes big investments.'

(Catalan; Quer 2001: 90)

In St'át'imcets, nominal restrictive relatives uniformly take indicative marking, as shown in (41). The distinction which is in Catalan is encoded by mood, is achieved by means of determiner choice in St'át'imcets (see Matthewson 1998, 1999 for analysis).

a. wa7 xat'-min'-ítas ti=kúkwpi7=a wa7

IMPF want-RED-3PL.ERG DET=chief=EXIS IMPF

ka-nuk'wa7-s-tanemwít-a mays

CIRC-help-CAUS-3PL.PASS-CIRC DET $=I M P F=3 P O S S$ fix

$\mathrm{ku}=$ tsetsítcw

DET $=$ houses

'They need a (particular) chief who can help them build houses.'

[WIDE-SCOPE INDEFINITE]

b. wa7 xat'-min'-ítas ku=kúkwpiz wa7

IMPF want-RED-3PL.ERG DET=chief IMPF

ka-nuk'wa7-s-tanemwít-a mays

CIRC-help-CAUS-3PL.PASS-CIRC DET $=I M P F=3$ POSS fix

$\mathrm{ku}=$ tsetsítcw

DET $=$ houses

'They need a(ny) chief who can help them build houses.'

[NARROW-SCOPE INDEFINITE] 
Cross-linguistic variation in modality systems: The role of mood

The mood effects seen in conditionals in some Indo-European languages are also absent in St'át'imcets. The antecedents of both notionally indicative and subjunctive conditionals are obligatorily marked with the subjunctive, as shown in (42), a paradigm borrowed from Quer 2009: 1780. Although there are ways to distinguish the different types of conditionals, they do not involve an indicative-subjunctive mood alternation.

(42) a. Context: I'm looking for John. You say:

$$
\begin{array}{ll}
\text { lh=7áts'x-en=an, } & \text { nílh=t'u7 s=qwál'-en-tsin } \\
\text { cOMP=see-DIR=1SG.SBJN FOC=PRT NOM=tell-DIR-2SG.OBJ }
\end{array}
$$

'If I see him, I'll tell you.'

b. Context: I'm looking for John, and I suspect you know where he is but you haven't been telling me. You say:

$$
\begin{aligned}
& \text { lh=7ats'x-en=án=ka, } \quad \text { sqwal'-en-tsín=lhkan=kelh } \\
& \text { cOMP=see-DIR=1SG.SBJN=IRR tell-DIR-2SG.OBJ=1SG.INDC=FUT }
\end{aligned}
$$

'If I saw him, I would tell you.'

c. Context: I was looking for John, but he left town before I could find him. You say:

$$
\begin{aligned}
& \text { lh=7ats'x-en=án=ka=tu7 } \\
& \text { cOMP=see-DIR=1SG.SBJN=IRR=then } \\
& \text { qwal'-en-tsín=lhan=ka } \\
& \text { tell-DIR-2SG.OBJ=1SG.INDIC=IRR }
\end{aligned}
$$

'If I had seen him, I would have told you.'

The St'át'imcets subjunctive is also not like the Mohawk one. Unlike in Mohawk, St'át'imcets futures take the indicative, as shown in (43); so do past habituals, as shown in (44), and plain negatives, as in (45).

$$
\begin{aligned}
& \text { a. ats'x-en-tsí=lhkan=kelh } \quad l \text { lh=nátcw=as } \\
& \text { see-DIR-2SG.OBJ=1SG.INDIC=FUT COMP=one.day.away=3SBJN } \\
& \text { 'I'll see you tomorrow.' } \\
& \text { b. } \quad \text { 'ats'X-en-tsín=an=kelh } \quad l h=\text { nátcw=as } \\
& \text { see-DIR-2SG.OBJ=1SG.SBJN=FUT COMP=one.day.away=3SBJN } \\
& \text { 'I'll see you tomorrow.' }
\end{aligned}
$$




$$
\begin{aligned}
& \text { wa7=lhkalh=wí7=tu7 } \quad \text { n-záw'-em } \quad \text { ku=qú7 } \\
& \text { IMPF=1PL.INDIC=EMPH=then LOC-get.water-MID DET=water } \\
& \text { lhel=ta=qú7qu7=a } \quad \text { múta } \quad \text { lhel=ta=tswáw'cw=a } \\
& \text { from=DET=water(PL)=EXIS and from=DET=creek=EXIS }
\end{aligned}
$$

'We used to fetch water from the spring and the creek.'

(Matthewson 2005: 370)

$$
\begin{aligned}
& \text { b. *wa7=at=wí7=tu7 n-záw'-em } \quad \text { ku=qú7 } \\
& \text { IMPF=1PL.SBJN=EMPH=then LOC-get.water-MID DET=water } \\
& \text { lhel=ta=qú7qu7=a múta7 lhel=ta=tswáw'cw=a } \\
& \text { from }=\mathrm{DET}=\text { water }(\mathrm{PL})=\text { EXIS and } \text { from }=\mathrm{DET}=\mathrm{creek}=\mathrm{EXIS}
\end{aligned}
$$

'We used to fetch water from the spring and the creek.'

$$
\begin{aligned}
& \text { a. áy=t'u7 } \mathrm{kw}=\mathbf{e n = g u ́ y ' t \quad k u = p a ́ l a 7} \text { sgap } \\
& \text { NEG=PRT DET=1SG.POSS=sleep DET=one evening }
\end{aligned}
$$

'I didn't sleep one night.'

(Matthewson 2005: 267)
b. *áy=t'u7 $\mathrm{kw}=\mathrm{s}=$ gúy't=an $\quad \mathrm{ku}=$ pála7 sgap
NEG=PRT DET=NOM=sleep=1SG.SBJN DET=one evening
'I didn't sleep one night.'

Finally, there are the cases where the St'át'imcets subjunctive does appear, with a predictable meaning difference, which are not attested in other languages. These include the use of the St'át'imcets subjunctive to weaken an imperative to a polite request, or to help turn a question into a statement of uncertainty (see examples in (13)-(15) and (16)-(20) above).

I will argue below that in spite of these major empirical differences between the St'át'imcets subjunctive and that of familiar languages, the basic framework for mood semantics advanced by Portner (1997) can be adapted to capture all the St'át'imcets facts. This will support Portner's proposal that moods are dependent on modals and place restrictions on the modal environments in which they appear.

\section{Basic framework: Portner 1997}

Portner's (1997) leading idea is that moods place presuppositions on the modal environment in which they appear. More precisely, moods typically restrict properties of the accessibility relation associated with a governing modal operator (see also Portner 2003: 64). The modal operator may be 
Cross-linguistic variation in modality systems: The role of mood

provided by a higher attitude verb or modal; it may also, in unembedded situations, be provided by context.

For illustration, let us first see how Portner analyzes English 'moodindicating may'. In each of the examples in (46), the may is not the ordinary modal may; it is not asserting possibility. (46b), for example, does not mean 'it is possible that it is possible that Sue wins the race.'

(46) a. Jack wishes that you may be happy.

b. It is possible that Sue may win the race.

c. May you have a pleasant journey!

(Portner 1997: 190)

Portner argues that mood-indicating may presupposes that $p$ is doxastically possible (possible according to someone's beliefs). For example, (46a) presupposes that Jack believes it is possible for you to be happy. He provides the analysis in (47).

(47) For any reference situation $r$, modal force $F$, and modal context $R$, $\llbracket m a y_{d e p}(\phi) \rrbracket^{r, F, R}$ is only defined if $\phi$ is possible with respect to $\operatorname{Dox}_{\alpha}(r)$, where $\alpha$ is the denotation of the matrix subject.

When defined, $\llbracket m a y_{d e p} \phi \rrbracket^{r, F, R}=\llbracket \phi \rrbracket^{r, F, R}$

(Portner 1997: 201)

Portner further argues that there are actually two mood-indicating may's, with slightly different properties. Mood-indicating may under wish, pray, etc. (as in (46a)) or in unembedded clauses (as in (46c)) has an extra requirement: it presupposes that the accessibility relation $R$ is buletic (deals with somebody's wishes or desires).

The discussion of mood-indicating may illustrates an important aspect of Portner's analysis, namely that moods place presuppositions on the modal accessibility relation (a type of conversational background). With English mood-indicating may, there is a doxastic and sometimes a buletic restriction. For the English mandative subjunctive, which appears in imperatives as well as in embedded contexts as in (48), $R$ must be deontic, as shown in (49).

(48) Mary demands that you join us downstairs at 3pm. (Portner 1997: 202)

(49) For any reference situation $r$, modal force $F$, and modal context $R$, $\llbracket \mathrm{m}-\operatorname{subj}(\phi) \rrbracket^{r, F, R}$ is only defined if $R$ is a deontic accessibility relation.

When defined, $\llbracket \mathrm{m}-\operatorname{subj}(\phi) \rrbracket^{r, F, R}=\llbracket \phi \rrbracket^{r, F, R} \quad$ (Portner 1997: 202) 
For Italian moods, Portner claims that $R$ is restricted to being (non-)factive. ${ }^{19}$ The idea that moods restrict modal conversational backgrounds is common to several other modal-based analyses of mood (e.g., Farkas 1992 and Giorgi \& Pianesi $1997^{20}$ ), and is also found in James 1986. What James calls 'manners of representation' are root vs. epistemic conversational backgrounds:

The ambiguity of the modal auxiliaries ... supports the hypothesis that there are two separate manners of representation. Moods ... signify manners of representation. They are not ambiguous, however; they signify one modality or the other (James 1986: 15).

In the analysis to follow, I will adopt Portner's idea that moods place restrictions on a governing modal operator. I will argue that the empirical differences between the St'át'imcets subjunctive and Indo-European subjunctives derive from the fact that the former restricts the conversational background of the modal operator in such a way that the modal force is weakened.

\section{Adapting Portner's approach for the Statimcets subjunctive}

I deal here only with the constructions where the subjunctive has a semantic effect; I will not address the cases of obligatory subjunctive agreement which were presented in subsection 2.2. ${ }^{21}$ My analysis will account for all meaningful uses of the St'át'imcets subjunctive except the two uses which contain the particle $t$ 'u7. See Section 8 for some discussion of the $t$ 'uz-constructions.

19 Interestingly, the Italian indicative imposes a modal force restriction as well as a conversational background restriction; it is only used with a force of necessity (Portner 1997: 197).

20 According to Giorgi and Pianesi, the subjunctive indicates that the ordering source is nonempty; this is a restriction on a conversational background.

21 The analysis presented below is actually compatible with the obligatory presence of the subjunctive in if-clauses introduced by $l h=$, and may even help to explain why $l h=$ obligatorily selects the subjunctive when it means 'if', but selects indicative when it means 'before'. Thanks to Henry Davis for discussion of this point, and see Davis 2006: chapter 26. (See also van Eijk 1997: 217, although van Eijk analyzes the subjunctive-inducing $l h=$ as distinct from (e)lh= 'before'.) As for the other obligatory cases of subjunctive, these may be grammaticized, semantically bleached relics of original meaningful uses, aided by the fact that subjunctive marking is intertwined with person agreement. 
Cross-linguistic variation in modality systems: The role of mood

\subsection{The St'át'imcets subjunctive presupposes rather than asserts a modal semantics}

The first thing to establish is that like Portner's moods, the St'át'imcets subjunctive does not itself assert a modal semantics, but is dependent on a governing modal operator. One piece of evidence for this is that the St'át'imcets subjunctive must co-occur with an overt modal in almost all its uses. Of the seven uses of the subjunctive being analyzed here, five of them have an overt modal (the deontics, 'pretend', wh-questions, yes-no questions, ignorance free relatives), one of them is plausibly analyzed as containing a covert modal (imperatives), and only one is non-modal (plain assertions). As noted above, the addition of the subjunctive to plain assertions is extremely restricted and at least semi-conventionalized. If the subjunctive were itself independently modal, it would be difficult to explain the minimal contrasts in (50)-(51). ${ }^{22}$

$$
\begin{aligned}
& \text { a. *gúy't=as ti=sk'úk'wm'it=a } \\
& \text { sleep=3SBJN DET=child=EXIS }
\end{aligned}
$$

Attempted: 'I hope the child sleeps.'

b. gúy't=as=ka ti=sk'úk'wm'it=a sleep $=\mathbf{3 S B J N}=$ DEON DET $=$ child $=$ EXIS

'I hope the child sleeps.'

a. *skalúl7=acw: saq'w knátiz múta7 em7ímnem
owl=2SG.SBJN fly DEIC and make.animal.noise

'Pretend to be an owl: fly around and hoot.'

b. skalúl7=acw=ka: saq'w knáti7 múta7 em7ímnem owl=2SG.SBJN=DEON fly DEIC and make.animal.noise

'Pretend to be an owl: fly around and hoot.'

Furthermore, just like with English mood-indicating may, the interpretation of St'át'imcets subjunctive clauses indicates that the mood does not

22 As noted above, Portner's analysis does allow for unembedded uses of non-indicative moods, with the modal accessibility relation being provided by context. So there is no problem with the cases where the St'át'imcets subjunctive can appear without a c-commanding modal (as in (5)-(6)). Of course, we would eventually like to explain when these unembedded subjunctives can and cannot appear. Portner (1997: 201) notes for mood-indicating may and the mandative subjunctive that 'Neither of these have a completely predictable distribution, in that neither occurs in every context in which a purely semantic account would predict that it could ... it must be admitted that lexical and syntactic idiosyncracies come into play.' 
itself contribute modal semantics. For example, (50b) does not mean 'It should be the case that the child should sleep'.

The St'át'imcets subjunctive also patterns morphosyntactically like a mood rather than like real modals in the language. As shown above, the subjunctive is obligatorily selected by some complementizers, unlike modals. The subjunctive is also fused with subject marking into a full paradigm, unlike the modals, which are independent second-position clitics. ${ }^{23}$ I therefore conclude that the St'át'imcets subjunctive does not itself introduce a modal operator, but requires one in its environment.

\subsection{The St'át'imcets subjunctive does not presuppose a particular con- versational background}

The Statimcets subjunctive differs from most Indo-European moods in that it cannot be analyzed as being restricted to a certain type of conversational background. This is illustrated by the fact that it allows deontic, buletic or epistemic uses. Deontic conversational backgrounds arise with imperatives, as in (52) or (14b), repeated here in (53):

$$
\begin{array}{ll}
\text { ets7á }=\mathbf{h a s}=(\text { malh }) & \text { lh=xílh-ts=al'ap } \\
\text { DEIC }=\mathbf{3 S B J N}=(\text { ADHORT }) & \text { cOMP=do-CAUS=2PL.SBJN }
\end{array}
$$

'Could you do it like this, you folks?'

$$
\begin{aligned}
& \text { nás=acw=malh áku7 pankúph=a } \\
& \text { go=2SG.SBJN=ADHORT DEIC Vancouver=EXIS } \\
& \text { 'You could go to Vancouver.' }
\end{aligned}
$$

Buletic conversational backgrounds arise with the modal $k a$ :

$$
\begin{aligned}
& \text { plan=as=ká=ti7=t'u7 wa7 máys-n-as } \\
& \text { already }=\mathbf{3 S B J N}=\mathbf{D E O N}=\text { DEMON }=\text { PRT IMPF fix-DIR-3ERG } \\
& \text { 'I wish he had fixed that already.' } \\
& \text { (55) guy't=ás=ka ti=sk'úk'wm'it=a } \\
& \text { sleep }=\mathbf{3 S B J N}=\mathbf{D E O N} \text { DET }=\text { child }=\text { EXIS } \\
& \text { 'I hope the child sleeps.' }
\end{aligned}
$$

23 Or in one case, a circumfix on the verb; see Davis et al. 2009. 
Cross-linguistic variation in modality systems: The role of mood

And epistemic conversational backgrounds arise with questions.

$$
\begin{array}{lll}
\text { nká7=as=kelh } & \mathrm{lh}=\mathrm{cú} z^{\prime}=\mathrm{acw} & \text { nas } \\
\text { where }=3 \text { SBJN=FUT } & \text { COMP=going.to=2SG.SBJN go }
\end{array}
$$

'Wherever will you go?' / 'I wonder where you are going to go now.' (adapted from Davis 2006: chapter 24)

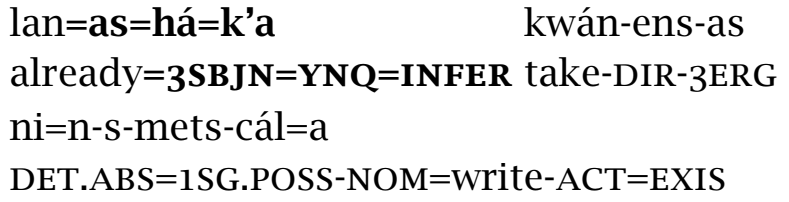

'I wonder if she's already got my letter.' / 'I don't know if she got my letter or not.'

These data suggest that the St'át'imcets subjunctive is not analyzable in the same way as the European moods discussed by Portner (1997), which hardwire a restriction to a particular type of conversational background.

\subsection{Instead, the St'át'imcets subjunctive functions to weaken the modal force}

The core idea of my proposal is that the St'át'imcets subjunctive restricts its governing modal only in such a way as to weaken the force of the proposition expressed. The intuition that the St'át'imcets subjunctive weakens the proposition it adds to was already expressed by Davis (2006: chapter 24):

The best way to characterize this meaning difference is in terms of the 'force' of a sentence. With ordinary indicative subjects, a sentence expresses a straightforward assertion, question or command; but with subjunctive subjects, the effect is to weaken the force of the sentence, so that an assertion becomes a wish, a question becomes a conjecture, and a command becomes a request.

The important question is what exactly is meant by 'weakening' in this context, and how to derive the various effects of the subjunctive in a unified way. I will claim that the St'át'imcets subjunctive restricts the conversational background of a governing modal in such a way that the modal imparts a force no stronger than weak necessity. Since there are no modals which 
lexically encode quantificational force in St'át'imcets, this will mean that the subjunctive must appear in the scope of a variable-force modal, and will restrict it to a weakened interpretation.

\section{Analysis}

The idea to be pursued is that the St'át'imcets subjunctive restricts the domain of quantification of a c-commanding modal, so that the interpretation which obtains is weaker than pure necessity. ${ }^{24}$ Rullmann et al. (2008) argue that St'át'imcets possesses no modals which are lexically restricted for a pure necessity reading (see also Matthewson et al. 2007 and Davis et al. 2009). Instead, all St'át'imcets modals seem to allow both weak and strong interpretations (see (3) above, and see the references cited for many more examples). So, what we need to say is that the subjunctive forces an already potentially weak c-commanding modal to have a weak reading. In order to see how this will work, I first very briefly review the basics of a Kratzerian analysis of modals, and then outline how modals in St'át'imcets are analyzed. We will then add the subjunctive.

Modals in a standard analysis introduce quantifiers over possible worlds. The set of worlds quantified over is narrowed down by two conversational backgrounds. First, it is narrowed down by the modal base, and then it is ordered and further narrowed down by the ordering source. The modal base and the ordering source are both usually provided by context in English, although there are systematic contributions of tense and aspect to the conversational background (see e.g., Condoravdi 2002 for discussion). A simple example is given in (58).

(58) Chris must do his homework.

Modal base (circumstantial): The set of worlds in which the relevant facts are the same as in the actual world (e.g., we ignore worlds where Chris is not in school).

Ordering source (normative): Orders worlds in the modal base so that the best worlds are those which come closest to the ideal represented by the school's homework regulations.

Universal quantification: In all the best worlds, Chris does his homework.

24 I would like to thank David Beaver and three anonymous reviewers for helping me clarify aspects of the analysis and its presentation. 
Cross-linguistic variation in modality systems: The role of mood

Rullmann et al. (2008) argue that there are two differences between English universal modals like must and St'át'imcets modals. First, the St'át'imcets modals place presuppositions on the conversational backgrounds. Second, the set of best worlds is further narrowed down by a choice function which picks out a potentially proper subset of the best worlds to be quantified over. This can lead to a weaker reading, depending on context. The idea is illustrated informally in (59). ${ }^{25}$

(59) gúy't=ka ti=sk'úk'wm'it=a

sleep $=$ DEON DET $=$ child $=$ EXIS

'The child must/should/can sleep.'

Modal base (presupposed to be circumstantial): Worlds in which the relevant facts about our family are the same as in the actual world. Ordering source (presupposed to be normative): The best worlds are those in which my desire for an early night is fulfilled.

Choice function: Picks out a potentially proper subset of the best worlds.

Universal quantification: In all worlds in the subset of the best worlds picked out by the choice function, the child sleeps.

Since the quantification is over a potentially proper subset of the best worlds, sentences like (59) can be interpreted with any strength ranging from a pure possibility ('The child can/may sleep') to a strong necessity ('The child must sleep'). The apparent variable quantificational force of St'át'imcets modals is thus derived not by ambiguity in the quantifier itself, but by restricting the size of the set of worlds quantified over by the universal quantifier. The larger the subset of the best worlds selected by the choice function, the stronger the proposition expressed. As a limiting case, the choice function may be the identity function. This results in a reading that is equivalent to the standard analysis of strong modals like must in English.

Now we turn to the subjunctive. In order to capture the idea that the subjunctive weakens the c-commanding modal, I analyze the subjunctive as presupposing that at least one world in the set of best worlds is a world in which the embedded proposition is false. This will prevent the choice

25 A very sensible suggestion that we should replace Rullmann et al.'s choice function with an(other) ordering source has been made independently by Kratzer (2009), Portner (2009), and Peterson (2009, 2010). I will in fact do this below when I compare the current analysis to that of von Fintel \& Iatridou (2008). 
function from being the identity function. ${ }^{26}$ This is illustrated informally for a deontic case in (6o).

$$
\begin{aligned}
& \text { guy't=ás=ka } \quad \text { ti=sk'úk'wm'it=a } \\
& \text { sleep=3SUBJ=DEON } \text { DET=child=EXIS }
\end{aligned}
$$

'I hope the child sleeps.'

Modal base (presupposed to be circumstantial): Worlds in which the relevant facts about our family are the same as in the actual world. Ordering source (presupposed to be normative): The best worlds are those in which my desire for an early night is fulfilled.

Choice function (must pick out a proper subset of the best worlds, to avoid a contradiction with the presupposition of the subjunctive): The very best worlds are those in which my spouse's desire for an early night is also fulfilled.

Universal quantification: All the very best worlds are worlds in which the child sleeps.

(59) allows a strong interpretation which (6o) disallows. If the choice function in (59) is the identity function, the speaker will be satisfied only if the child sleeps ('in all the worlds where my desire for an early night is fulfilled, the child sleeps'). In (6o), the speaker will certainly be satisfied if the child sleeps, but there are also other ways to make him/her happy. (6o) asserts only that 'in all the worlds where my and my spouse's desires for an early night are fulfilled, the child sleeps' - so the speaker's desires may be satisfied if the speaker's spouse looks after the child while the speaker goes to sleep. The requirement that (6o) places on the child is thus weaker than a strong necessity.

In the remainder of this section I provide a more formal implementation of this idea, and in Section 7 I show how the analysis accounts for a wide range of uses of the St'át'imcets subjunctive, including imperative-weakening, question-weakening, and ignorance free relatives.

26 Thanks to Hotze Rullmann (p.c.) for discussion of this point. The requirement that $p$ be false in at least one of the best worlds appears reminiscent of a nonveridicality-style analysis, and there may be some deep significance to this. However, the analyses are different. For Giannakidou, the issue is always epistemic, as veridicality is defined in terms of a truth entailment in an individual's epistemic model; see (37). Thus, subjunctive is predicted under verbs like 'want', as propositions under 'want' are not entailed to be true in any individual's epistemic model. Under my analysis, the subjunctive has an anaphoric modal base and ordering source. I will show in subsection 7.5 that my analysis correctly predicts the indicative under verbs like 'want' in St'át'imcets. 
Cross-linguistic variation in modality systems: The role of mood

I adopt the following basic definitions from von Fintel \& Heim 2007. (61) shows the ordering of worlds according to how well they satisfy the set of propositions in the ordering source, and (62) shows how the best worlds are selected.

(61) Given a set of worlds $X$ and a set of propositions $P$, define the strict partial order $<_{P}$ as follows:

$\forall w_{1}, w_{2} \in X: w_{1}<_{P} w_{2}$ iff $\left\{p \in P: p\left(w_{2}\right)=1\right\} \subset\left\{p \in P: p\left(w_{1}\right)=1\right\}$

For any worlds $w_{1}$ and $w_{2}, w_{1}$ comes closer to the ideal set up by the ordering source than $w_{2}$ does iff the set of propositions in the ordering source which are true in $w_{2}$ is a proper subset of the set of propositions in the ordering source which are true in $w_{1}$.

(62) For a given strict partial order $<_{p}$ on worlds, define the selection function $\max _{P}$ that selects the set of $<_{P}$-best worlds from any set $X$ of worlds:

$$
\forall X \subseteq W: \max _{P}(X)=\left\{w \in X: \neg \exists w^{\prime} \in X: w^{\prime}<_{P} w\right\}
$$

(von Fintel \& Heim 2007: 55)

The best worlds are those for which there are no worlds closer to the ideal than they are. The analysis of English must is given in (63). must takes as arguments a modal base, an ordering source and a proposition, and asserts that in all the best worlds in the modal base, as defined by the ordering source, the proposition is true. ${ }^{27,28}$

$$
\begin{gathered}
\llbracket m u s t \rrbracket^{c, w}=\lambda h_{\langle s,\langle s t, t\rangle\rangle} \cdot \lambda g_{\langle s,\langle s t, t\rangle\rangle} \cdot \lambda q_{\langle s, t\rangle} \cdot \forall w^{\prime} \in \max _{g(w)}(\cap h(w)): q\left(w^{\prime}\right)=1 \\
(\operatorname{von} \text { Fintel \& Heim 2007: 55) }
\end{gathered}
$$

The analysis of St'át'imcets normative $k a$ is given in (64). $k a$ takes as arguments a modal base, an ordering source, and a proposition. $f_{c}$ represents the contextually given choice function.

27 Nothing crucial hinges on having the conversational backgrounds present in the syntax (as in von Fintel \& Heim 2007) rather than being parameters of interpretation (as in Portner 1997). However, the syntactic version may have a potential advantage in enforcing the required anaphoricity of the conversational backgrounds once we bring in the subjunctive. In Rullmann et al.'s (2008) analysis of St'át'imcets modals, the choice function is also a syntactic argument of the modal. Following the suggestion of an anonymous reviewer, I have changed this here, but again, nothing crucial hinges on the decision.

28 As an anonymous reviewer reminded me, English must also encodes restrictions on its modal base and ordering source, parallel to (but obviously different from) those defined for $k a$ in (64). See for example von Fintel \& Gillies 2010 and Matthewson 2010, to appear for discussion. 
(64) $\llbracket k a(h)(g) \rrbracket^{c, w}$ is only defined if $h$ is a circumstantial modal base and $g$ is a normative ordering source.

If defined, $\llbracket k a(h)(g) \rrbracket^{c, w}=\lambda q_{\langle s, t\rangle} . \forall w^{\prime} \in f_{c}\left(\max _{g(w)}(\cap h(w))\right): q\left(w^{\prime}\right)=1$ (adapted from Rullmann et al. 2008: 340)

Now for the subjunctive. As shown in (65), the subjunctive does not affect truth conditions but merely enforces a weaker-than-necessity reading of a modal in the environment. The subjunctive does not itself introduce any conversational backgrounds; $h$ and $g$ in (65) are free variables. I assume that this enforces anaphoricity: the mood must be c-commanded by a modal which introduces $h$ and $g .{ }^{29}$

$\llbracket \operatorname{SBJN}(\phi) \rrbracket^{c, w}$ is only defined if $\exists w^{\prime} \in \max _{g(w)}(\cap h(w))\left[\phi\left(w^{\prime}\right)=0\right]$.

When defined, $\llbracket \operatorname{SBJN}(\phi) \rrbracket^{c, w}=\lambda w^{\prime} \cdot \llbracket(\phi) \rrbracket^{c, w^{\prime}}$

According to (65), the subjunctive is only defined if there is at least one world $w^{\prime}$ in the set of best worlds in the modal base, as defined by the ordering source, such that $\phi$ is false in $w^{\prime}$. The analysis is applied to a normative subjunctive case in (66).

$$
\begin{aligned}
& \text { guy't=ás=ka } \quad \text { ti=sk'úk'wm'it=a } \\
& \text { sleep=3SUBJ=DEON } \text { DET=child=EXIS }
\end{aligned}
$$

'I hope the child sleeps.'

$\llbracket k a(h)(g)\left(a s\left(g u y ' t\right.\right.$ ti sk'úk'wm'ita)) $\rrbracket^{c, w}$ is only defined if

i. $h$ is a circumstantial modal base and $g$ is a normative ordering source

ii. $\exists w^{\prime} \in \max _{g(w)}(\cap h(w))$ [the child doesn't sleep in $w^{\prime}$ ]

When defined, $\llbracket k a(h)(g)($ as (guy't ti sk'úk'wm'ita) $) \rrbracket^{c, w}=1$ iff $\forall w^{\prime} \in f_{c}\left(\max _{g(w)}(\cap h(w))\right)$ [the child sleeps in $w^{\prime}$ ]

As above, $\max _{g(w)}(\cap h(w))$ picks out the best worlds in the modal base, as defined by the normative ordering source. The contextually determined choice function $f_{c}$ picks out a subset of $\max _{g(w)}(\cap h(w))$, and the modal universally quantifies over the set picked out by the choice function. Because the subjunctive mood presupposes that there is at least one world

29 Thanks to an anonymous reviewer for pointing out an inconsistency in an earlier version of (65). 
Cross-linguistic variation in modality systems: The role of mood

in $\max _{g(w)}(\cap h(w))$ in which the proposition is false, the choice function must pick out a proper subset of the worlds provided by the modal base and ordering source. This forces a weaker-than-universal reading. We in fact predict gradient readings with the subjunctive - anything from pure possibility to weak necessity. This seems to fit with the facts about when the subjunctive is felicitous.

I have so far been simply following Portner (1997) in modeling the mood restriction as a presupposition, rather than as ordinary asserted content, or some other kind of inference. The question arises of whether there is any St'át'imcets-internal justification for the assumption that presupposition is involved. ${ }^{30}$

If the subjunctive contributed ordinary asserted content, we would predict that it would fail to project through presupposition holes such as negation or conditionals, and that it could be directly affirmed or denied by the hearer. The issue of projection through presupposition holes is not testable for most of the relevant constructions in St'át'imcets. For example, negation in St'át'imcets is a predicate which embeds an obligatorily nominalized (i.e., indicative) subordinate clause. When a subjunctive clitic does co-occur with negation, it attaches to the negation itself, as shown in (67). Thus, while (67) is not interpretable in a way which would show that the subjunctive contributed asserted content, the results are not conclusive because the subjunctive is probably not scoping under negation syntactically.

$$
\begin{aligned}
& \text { cw7aoz=as=ká=t'u } \quad \mathrm{kw}=\mathrm{s}=\mathrm{nas}=\mathrm{ts} \\
& \mathrm{NEG}=3 \text { SBJN }=\mathrm{DEON}=\mathrm{PRT} \text { DET }=\mathrm{NOM}=\mathrm{gO}=3 \mathrm{POSS}
\end{aligned}
$$

'I wish he wouldn't go.'

(van Eijk 1997: 214)

* 'It is not the case that [in at least one of the best worlds in the modal base, he doesn't go, and in all of the set of worlds selected by the choice function, he goes].'

i.e, $\neq$ 'It is not the case that [it's good if he goes, and I can still be happy if he doesn't].'

Nor can we test projection through 'if', as 'if'-clauses obligatorily and redundantly select the subjunctive in St'át'imcets (see subsection 2.2). However, questions provide evidence that the subjunctive does not contribute ordinary asserted content. Recall that the subjunctive plus an inferential evidential

30 Thanks to David Beaver and an anonymous reviewer for asking for clarification of this issue. 
when added to a question results in a statement of uncertainty (16)-(20). The question in (68) cannot be interpreted as if the subjunctive contributed asserted content which scopes below the question. (See subsection 7.2 for analysis of questions like (68).)

$$
\begin{array}{lll}
\text { nilh=as=há=k'a } & \text { s=Lémya } & \text { ku=kúkwpi7 } \\
\text { FOC=3SBJN=YNQ=INFER } & \text { NOM=Lémya7 } & \text { DET=chief }
\end{array}
$$

'I think maybe Lémyaz is the chief / I wonder if Lémyaz is the chief.' $\neq$ 'Is it the case that [in at least one of the best worlds compatible with the inferential evidence, Lémyaz is not the chief, and in all of the set of worlds selected by the choice function, Lémyaz is the chief]?'

i.e, $\neq$ 'Is it the case that [Lémya7 is possibly but not necessarily the chief]?'

Further evidence that the subjunctive does not contribute ordinary asserted content comes from the impossibility of directly affirming or denying its contribution. This is shown in (69), where B and B' try to deny A's subjunctive claim that in at least one world compatible with A's knowledge and desires, the children don't sleep. The consultant absolutely rejects the replies in B and B'.

$$
\begin{aligned}
& \text { A guy't=ás=ka i=sk'wemk'úk'wm'it=a } \\
& \text { sleep=3SBJN=DEON DET.PL=child(PL)=EXIS } \\
& \text { 'I hope the children sleep.' } \\
& \text { B \#cw7aoz kw=s=wenácw. plán=lhkacw zewát-en } \\
& \text { NEG DET=NOM=true already=2SG.SUBJ know-DIR } \\
& \text { kW=s=cuz' gúy't=wit } \\
& \text { DET=NOM=going.to sleep=3PL } \\
& \text { 'That's not true. You already know they will sleep.' } \\
& \text { \#cw7aoz kw=s=wenácw. lh=cw7áoz=as } \\
& \text { NEG DET=NOM=true COMP=NEG=3SBJN } \\
& \text { kw=s=gúy't=wit i=sk'wemk'úk'wm'it=a, áoz=kelh } \\
& \text { DET=NOM=sleep=3PL DET.PL=child(PL)=EXIS NEG=FUT } \\
& \text { kw=a=s áma ta=scwákwekw-sw=a } \\
& \text { DET=IMPF=3POSS good DET=heart-2SG.POSS=EXIS }
\end{aligned}
$$

'That's not true. If the children don't sleep, you won't be happy.'

Having established that the weakening contribution of the subjunctive is not ordinary asserted content, the question now is whether it contributes a 
Cross-linguistic variation in modality systems: The role of mood

presupposition per se, or some other not-at-issue content, such as a Potts (2005)-style conventional implicature. One major empirical difference between a traditional understanding of presuppositions (e.g., Stalnaker 1974) and conventional implicatures is that only the former impose constraints on the state of the common ground. Conventional implicatures, in contrast, standardly contribute information which is new to the hearer (Potts 2005). I have argued elsewhere (Matthewson 2006, 2008b) that St'át'imcets entirely lacks presuppositions of the common ground type; all not-at-issue content in this language is treated as potentially new to the hearer. ${ }^{31}$ In those earlier works I argued that the St'át'imcets facts necessitate an alternative analysis of presupposition (for example that of Gauker 1998). However, another way to look at things is to say that out of the class of not-at-issue meanings, St'át'imcets lacks one sub-type, namely common ground presuppositions. What I have modeled as a presupposition of the St'át'imcets subjunctive would then be some other kind of not-at-issue content, perhaps a conventional implicature. However, these issues go beyond the scope of the present paper and do not affect the main points being made here, so with these caveats I will continue to model the subjunctive as introducing a presupposition.

Before turning to more complex constructions involving the subjunctive, it is interesting to consider the similarity between the analysis of the St'át'imcets subjunctive provided here and von Fintel \& Iatridou's (2008) ideas about weak necessity modals. von Fintel and Iatridou are concerned with the difference in quantificational strength between ought and have to/must. In $(70)$, we see that the restriction on employees is stronger than that on everyone else.

(70) After using the bathroom, everybody ought to wash their hands; employees have to.

(von Fintel \& Iatridou 2008: 116)

(71) also illustrates the contrast between the different modal strengths. In (71a), taking Route 2 is the only option, if you want to get to Ashfield: all the worlds in which you get to Ashfield are Route 2-worlds. In (71b), there are other getting-to-Ashfield worlds apart from only Route 2-worlds. But the Route-2 worlds are the best, taking into consideration some other factors (such as a scenic route).

31 For example, attempts to elicit 'Hey, wait a minute!' responses to presupposition failures for a wide range of standard presupposition triggers have all failed (Matthewson 2006, 2008b). We are therefore unable to decide the presupposition issue for the subjunctive by using the 'Hey, wait a minute!' test (as was suggested by an anonymous reviewer). 
Lisa Matthewson

(71) a. To go to Ashfield, you have to / must take Route 2.

b. To go to Ashfield, you ought to take Route 2.

(von Fintel \& Iatridou 2008: 118)

von Fintel and Iatridou argue that ought is a weak necessity modal, and that weak necessity modals signal the existence of a secondary ordering source. This is illustrated informally in (72)-(73). (72) contains a strong necessity modal, and gives a strong reading, as usual. In (73), a secondary ordering source further restricts the set of worlds which are universally quantified over, leading to a weaker reading.

(72) To go to Ashfield, you have to / must take Route 2.

Modal base: Restricts worlds considered to those in which the same facts about roads hold as in the actual world.

Ordering source: Orders worlds in the modal base so that the best worlds are those in which you attain your goal of getting to Ashfield. Universal quantification: In all the best worlds, you take Route 2.

(73) To go to Ashfield, you ought to take Route 2.

Modal base: Restricts worlds considered to those in which the same facts about roads hold as in the actual world.

Ordering source 1: Orders worlds in the modal base so that the best worlds are those in which you attain your goal of getting to Ashfield. Ordering source 2: Further orders the best worlds picked out by ordering source 1, so that the very best worlds are those in which you not only attain your goal of getting to Ashfield, but also attain an additional goal of going via a scenic route.

Universal quantification: In all the very best worlds, you take Route 2.

As von Fintel \& Iatridou (2008: 137) put it: 'The idea is that saying that to go to Ashfield you ought to take Route 2, because it's the most scenic way, is the same as saying that to go to Ashfield in the most scenic way, you have to take Route 2.' This is very parallel in spirit to Rullmann et al.'s (2008) analysis of St'át'imcets modals, where a weak reading is obtained by a universal quantifier with a restriction provided by a choice function. And just like Rullmann et al.'s analysis, von Fintel and Iatridou's actually predicts gradience: how 'weak' a weak necessity modal is can vary, depending on 
Cross-linguistic variation in modality systems: The role of mood

which secondary ordering source you pick. In fact, given that the motivation for using a choice function rather than an ordering source was unconvincing anyway (cf. Kratzer 2009, Peterson 2009, 2010, and Portner 2009), the Rullmann et al.-style analysis is better implemented using a double ordering source, exactly as in von Fintel \& Iatridou 2008. ${ }^{32}$

So what is the difference between English and St'át'imcets? Simply that in English, we lexically encode the weak necessity (ought vs. have to/must). In St'át'imcets, no differences in modal force are lexically encoded by modals, but what English modals do, St'át'imcets does via mood. Another way of describing the analysis offered here would be to say that the St'át'imcets subjunctive enforces weak necessity (via domain restriction): it forces there to be two (non-vacuous) restrictions on the set of worlds in the modal base.

While further cross-linguistic investigation goes beyond the scope of this paper, it is worth pointing out a connection to another intriguing observation of von Fintel and Iatridou's, namely that in many languages, weak necessity modals are created transparently from a strong necessity modal plus counterfactual morphology. This is illustrated in (74) for French, where the modal appears in the conditional mood, the one which occurs in counterfactual conditionals.

(74) tout le monde devrait se laver les mains mais les serveurs everybody must/COND REFL wash the hands but the waiters sont obligés

are obliged

'Everybody ought to wash their hands but the waiters have to.'

(von Fintel \& Iatridou 2008: 121)

This is very reminiscent of St'át'imcets, where a modal which introduces universal quantification gives rise to weak necessity interpretations in the presence of the subjunctive. In St'át'imcets, I have analyzed the weakening effect as the sole contribution of the subjunctive mood. Of course, 'counterfactual' and 'subjunctive' are not the same thing, and I am not in a position to claim that the current analysis of the subjunctive can extend to counterfactual morphology in the languages discussed by von Fintel and Iatridou. However, the present analysis at the very least supports von Fintel and Iatridou's cross-linguistic generalization that mood morphology can derive weak

32 Like von Fintel and Iatridou, I omit a formal definition of a modal with a double ordering source; see von Fintel \& Iatridou 2008: 138 for some suggestions on how to do this. 
necessity interpretations, and may offer a potential new avenue for looking at languages like French.

\section{Applying the analysis to other subjunctive constructions}

In the previous section I presented an analysis of the St'át'imcets subjunctive and applied it to cases involving a normative modal. In this section I aim to establish that the analysis of the subjunctive as restricting the conversational background of a co-occurring modal can extend to the other uses of the subjunctive. I deal in turn with imperatives (subsection 7.1), questions (subsection 7.2), ignorance free relatives (subsection 7.3), the 'pretend' cases (subsection 7.4), and finally I return to the fact that in St'át'imcets, the subjunctive is not licensed by any attitude verbs (subsection 7.5).

\subsection{Imperatives}

Recall that the subjunctive, when added to an imperative, makes the command more polite. An example is repeated here:

$$
\begin{aligned}
& \text { a. lts7á=malh lh=kits-in'=ál'ap! } \\
& \text { DEIC=ADHORT COMP=put.down-DIR=2PL.SBJN } \\
& \text { 'Just put it over here!' } \\
& \text { b. lts7á=has=malh } \quad l h=k i t s-i n '=a ́ l ' a p \\
& \text { DEIC=3SBJN=ADHORT COMP=put.down-DIR=2PL.SBJN }
\end{aligned}
$$

'Could you put it down here?'/'You may as well put it down over here.'

The easiest way to analyze the imperatives would be as sub-cases of the deontic cases already analyzed above. We could say that the imperative introduces a deontic necessity modal, and the subjunctive weakens the proposition expressed. That is what I will in fact say, adopting Schwager's (2005, 2006) analysis of imperatives.

Schwager (2005, 2006) claims that imperatives introduce a modal operator, which is a more restricted version of a deontic necessity modal. ${ }^{33}$ Normally, the imperative modal expresses necessity, with the Common Ground

33 See Han 1997, 1999 for an earlier proposal of a similar idea. Han's modal analysis shares many of the advantages for St'át'imcets of Schwager's approach. However, since Han models the modal claim of the imperative as a presupposition rather than part of the assertion, extra assumptions would be required to apply it to St'át'imcets subjunctive imperatives. 
Cross-linguistic variation in modality systems: The role of mood

serving as the modal base, and a contextually given set of preferences giving the ordering source. In addition, imperatives carry presuppositions, as shown in (76). The presuppositions restrict an imperative to situations where a performative use of a deontic modal would be possible, namely those in which the speaker is an authority on the matter. ${ }^{34}$

(76) Presuppositions of an imperative:

1. The speaker is an authority on the parameters. [modal base and ordering source]

2. The ordering source is preference-related. ${ }^{35}$

3. The speaker affirms the ordering source as a good maxim for acting in the given scenario.

(Schwager 2006: 248-249)

A simple case is illustrated in (77).

(77) Get up!

Modal base: What the speaker and hearer jointly take to be possible Ordering source: The speaker's commands

(77) is true iff all worlds in the Common Ground that make true as much as possible of what the speaker commands at the world and time of utterance make it true that the addressee gets up within a certain event frame $t$ (Schwager 2005: chapter 6). The difference between (77) and the plain modal statement 'You must get up' is that with the imperative, the speaker is presupposed to be an authority. This has the consequence that whenever an imperative is defined, it is necessarily true.

Adopting Schwager's analysis enables us to treat the St'át'imcets subjunctive imperatives the same way we treated the weakened normative $k a$ statements above. We have to assume that the deontic modal in a St'át'imcets imperative is, like the overt $k a$, a universal modal which introduces a choice function or secondary ordering source. While a normal imperative roughly says that in all the best worlds (the worlds where you obey my commands),

34 The descriptive vs. performative use of a deontic modal is shown in (i), from (Schwager 2008: 26).

(i) a. Peter may come tomorrow. (The hostess said it was no problem.) DESCRIPTIVE

b. Okay, you may come at 11. (Are you content now?)

PERFORMATIVE

35 The preferences may relate to the addressee's wishes, as in the case of advice or suggestions. 
you do P, a subjunctive imperative presupposes that at least one world in which you obey my commands is a world in which you do not do P. This predicts that a weakened imperative means that in the very best worlds, you do P, but there are other ways to satisfy me. The requirement on the addressee becomes weaker, just as the requirement on the child to sleep becomes weaker in the examples discussed above.

An advantage of Schwager's analysis for St'át'imcets is that it makes the correct predictions for 'permission imperatives' like 'Have a cookie!' These do not perform a speech act of ordering, but rather of invitation. It might be natural to think that permission imperatives involve a possibility modal, but Schwager argues that imperatives always introduce a necessity operator. For Schwager, the permission effect arises due to the contextual parameters; this is shown in (78).

(78) Take an apple if you like!

Given what we know the world to be like and given what you want, it is necessary that you take an apple. (cf. Schwager 2008: 49)

Under Schwager's analysis, then, the difference between an order and an invitation consists not in a difference in quantificational force, but in ordering source. This correctly predicts that in St'át'imcets, permission imperatives do not have to take the subjunctive: ${ }^{36,37}$

(79) Context: Your friend comes over and is visiting with you. You hear her stomach rumbling. You give her a plate and say 'Have some cake!'
a. wá7=malh kiks-tsín-em
be $=$ ADHORT cake-eat-MID
'Have some cake!'
b. \#wá7=acw=malh kiks-tsín-em
be $=\mathbf{2 S G}$.SBJN=ADHORT cake-eat-MID
'You may as well have some cake.'

$36(79 \mathrm{~b})$ is marked as infelicitous in this context, which is how the consultant judges it. (8ob) appears to be ungrammatical. The difference possibly relates to the presence in (79b) of the adhortative particle malh, an interesting element whose analysis must await future research.

37 An anonymous reviewer points out that permission imperatives should be able to take the subjunctive in certain circumstances, meaning something like 'the very best way to achieve your desires is p, though there are other ways'. Future research is required to see whether this prediction is upheld once the right discourse contexts are provided. 
Cross-linguistic variation in modality systems: The role of mood

(80) Context: You are at a gathering and they are almost running out of food. You take the last piece of fish and then you see an elder is behind you and is looking disappointed and has no fish on her plate. You say 'Take mine!'
a. kwan ts7a ti=n-tsúw7=a
take(DIR) DEIC DET=1SG.POSS-Own=EXIS
'Take mine!'
b. *kwán=acw ts7a ti=n-tsúw7=a take(DIR)=2SG.SBJN DEIC DET=1SG.POSS-own=EXIS intended: 'Take mine!'

We have seen that an analysis of imperatives as containing a concealed necessity modal works for St'át'imcets. In the remainder of this section I briefly discuss the alternative analysis of Portner (2004, 2007).

Portner's (2004, 2007) analysis of imperatives relies on the notion of a 'To-Do List'. The idea is that each participant in a conversation has a To-Do List, a set of properties which they are committed to satisfying. The To-Do list Function (which maps each participant to their own To-Do List) is a component of the Discourse Context (along with the Common Ground and the Question Set). An imperative, as in (81), denotes a property whose subject is the addressee. This causes the property to be added to the addressee's To-Do List.

$$
\llbracket \text { Leave! } \rrbracket^{w *, c}=[\lambda w \lambda x: x=\text { addressee }(c) . x \text { leaves in } w]
$$

Similarly to in Schwager's analysis, 'permission' imperatives are dealt with in Portner's analysis by the counterpart of the ordering source, namely different sub-sets of the To-Do List. The To-Do List is divided into deontic, bouletic and teleological sub-parts, corresponding to orders, invitations, and suggestions respectively. The addressee can therefore keep track of actions she is supposed to take to satisfy someone's orders, her own wishes, or her own goals.

An important feature of this analysis is that under the To-Do List approach, imperatives do not contain modal operators. While for Portner, imperatives and root modals are closely linked - for example, the successful utterance of an imperative leads to the truth of a corresponding sentence containing a root modal - imperatives do not themselves contain modals. ${ }^{38}$

38 See Portner 2007: 363ff for arguments against Han's (1999) and Schwager's (2005, 2006) analysis of imperatives as containing concealed modals. 
My analysis of the St'át'imcets subjunctive, however, seems to require the presence of a modal, whose force is functionally weakened via a restriction on the conversational background. A unified analysis of the St'át'imcets subjunctive across all its uses would therefore seem to require a modal in the imperative.

However, as pointed out by an anonymous reviewer, Portner's analysis of imperatives will work for St'át'imcets. The lexical entry for the subjunctive given above in (65) does not literally require the presence of a governing modal; it merely requires the presence of contextually available conversational backgrounds. These are provided within Portner's analysis, given that the Common Ground corresponds to (at least a subset of) a circumstantial modal base, while a To-Do List corresponds to (at least a subset of) a deontic, bouletic or teleological ordering source. To apply Portner's analysis to St'át'imcets, we only need to assume that the imperative morpheme can take the Common Ground plus two To-Do Lists as arguments. The subjunctive will presuppose that there is a world among the best worlds in the Common Ground, according to To-Do List 1, in which the imperative is not satisfied. Assuming that the second To-Do List is 'more ignorable' than the first (cf. also von Fintel and Iatridou 2008 on the primacy of the first ordering source), then a hearer can decide to be bound either by both To-Do Lists, or only by the first. If the speaker has set up her own desires as the secondary To-Do List, we obtain the politeness reading typical of a St'át'imcets subjunctive imperative.

In summary, we have seen that our analysis of the St'át'imcets subjunctive extends to the weakened imperatives, as long as we assume that imperatives are concealed normative modal statements, or at least provide the same conversational backgrounds as a normative modal. This idea can be implemented within either the approaches of Schwager (2005, 2006, 2008) or Portner $(2004,2007)$.

\subsection{Questions}

The subjunctive appears, in combination with an evidential or future modal, in both yes-no and wh questions in St'át'imcets, in each case turning the question into a statement of uncertainty. Some examples are repeated here. Following Littell, Matthewson \& Peterson (2009), I use the term 'conjectural question' for this construction. 
Cross-linguistic variation in modality systems: The role of mood

a. lán=ha kwán-ens-as

already=YNQ take-DIR-3.ERG

ni $=$ n-s-mets-cál $=\mathrm{a}$

DET.ABS=1sg.POSS-NOM-write-ACT=EXIS

'Has she already got my letter?'

b. lan=as=há=k'a kwán-ens-as

already=3.SBJN $=$ YNQ $=$ INFER take-DIR-3.ERG

ni=n-s-mets-cál=a

DET.ABS=1sg.POSS-NOM-write-ACT=EXIS

'I wonder if she's already got my letter.' / 'I don't know if she got my letter or not.'

a. nká7=kelh $\mathrm{lh}=\mathrm{cú} \mathrm{z}^{\prime}=\mathrm{acw}$ nas

where $=$ FUT COMP=going.to $=2$ SG.SBJN go

'Where will you go?'

b. nká $=$ =as=kelh $\quad l \mathrm{l}=$ cúz' $=\mathrm{acw} \quad$ nas

where $=\mathbf{3 S B J N}=\mathbf{F U T} \mathbf{C O M P}=$ going.to $=2 \mathrm{SG} . \mathrm{SBJN}$ go

'Wherever will you go?' / 'I wonder where you are going to go now.' (adapted from Davis 2006: chapter 24)

Previous discussion of conjectural questions in Salish includes Matthewson 2008a, Littell et al. 2009 and Littell 2009. ${ }^{39}$ The analysis given here will essentially be that of Littell (2009), with the addition of an account of the role of the subjunctive (which Littell does not discuss), and an extension to cases where the subjunctive in a conjectural question is licensed by a future modal, rather than an evidential.

The paradigms in (84) and (85) illustrate the distributional facts for conjectural questions which contain an evidential (as opposed to a future modal). We see that the evidential is obligatory (the (b) examples), but the subjunctive - while strongly preferred - is not quite obligatory (the (c) examples). ${ }^{40}$

$$
\begin{aligned}
& \text { a. } \text { t'íq }=\varnothing=\text { ha } \quad \mathrm{k}=\text { Bill } \\
& \text { arrive }=\text { INDIC=YNQ DET=Bill } \\
& \text { 'Did Bill arrive?' }
\end{aligned}
$$

INDIC

39 Littell et al. (2009) investigate conjectural questions in three languages: St'át'imcets, Nłe?kepmxcín (Thompson Salish) and Gitksan, while Littell (2009) focuses mainly on Nłe?kepmxcín.

40 While subjunctive evidential questions (as in $(84 \mathrm{~d}),(85 \mathrm{~d})$ ) are obligatorily interpreted as statements of uncertainty rather than questions, indicative evidential questions (as in (84c), (85c)) can optionally be interpreted as ordinary questions. I return to this below. 
b. *t'íq =as=ha $\quad \mathrm{k}=$ Bill

arrive $=\mathbf{3 S B J N}=$ YNQ DET $=$ Bill $\quad$ SBJN

c. ?t'íq=ha=k'a k=Bill

arrive $=\mathrm{YNQ}=$ INFER DET $=$ Bill

'I wonder if Bill arrived.'

EVID + INDIC

d. t'iq=as=há=k'a k=Bill

arrive $=\mathbf{3 S B J N}=\mathrm{YNQ}=\mathbf{I N F E R}$ DET $=$ Bill

'I wonder if Bill arrived.'

EVID + SBJN

(85) a. ínwat=wit

say.what $=\mathbf{3 P L}$

'What did they say?'

INDIC

b. *inwat=wít=as

say. what $=3 \mathrm{PL}=3$ SBJN

SBJN

c. ??inwat=wít=k’a

say.what $=3$ PL $=$ INFER

'I wonder what they said.'

EVID + INDIC

d. inwat=wít=as=k'a

say. what $=3 P L=3$ SBJN $=$ INFER

'I wonder what they said.'

EVID + SBJN

As argued in the above-mentioned references, conjectural questions have the syntax and the semantics of a question, but the pragmatics of an assertion (as they do not require an answer in discourse). With respect to syntax, conjectural questions clearly pattern with ordinary questions. Littell et al. (2009) point out that not only do conjectural questions contain the normal yes-no question particle or sentence-initial wh-phrase plus extraction morphology, they embed under the same predicates as ordinary questions do. This is shown in (86).

$$
\begin{aligned}
& \text { aoz } \mathrm{kW}=\mathrm{S}=\mathrm{z} \text { wát-en-as } \quad \mathrm{k}=\text { Lisa } \\
& \text { NEG DET=NOM=know-DIR-3ERG DET=Lisa } \\
& \text { lh=wa7=as=há=k'a áma-s-as k=Rose ku=tíh } \\
& \text { COMP=IMPF=3SBJN=YNQ=INFER good-CAUS-3ERG DET=Rose DET=tea }
\end{aligned}
$$

'Lisa doesn't know whether Rose likes tea.' 
Cross-linguistic variation in modality systems: The role of mood

The ability to embed under question-taking predicates is prima facie evidence that conjectural questions have the same semantic type as ordinary questions.

Pragmatically, however, conjectural questions do not behave like ordinary questions, because conjectural questions do not require an answer from the addressee. In fact, conjectural questions are infelicitous in any situation where the hearer can be assumed to know the answer. This is illustrated in $(87) .^{41}$
a. ??lan=acw=há=k'a
q'a7

already $=$ 2SG.SBJN $=$ YNQ $=$ INFER eat

'I wonder if you've already eaten.'

b. Context: You see your friend wearing a watch and you say:

??zwat-en=ácw=ha=k’a

knOW-DIR=2SG.SBJN $=$ YNQ $=$ INFER

lh=k'wín=as=t'elh

$\mathrm{COMP}=$ how. many $=3 \mathrm{SBJN}=$ now

'Would you know what the time was?'

Consultant's comment: "You wouldn't have seen the watch if you say this."

Nor are conjectural questions a type of rhetorical question. Han (2002) argues that rhetorical questions have the force of a negative assertion, as in (88).

(88) Did I tell you it would be easy? $\approx$ I didn't tell you it would be easy.

But this is not the meaning we get in St'át'imcets for conjectural questions. In order to express a true rhetorical question, St'át'imcets speakers use something which is string-identical to an ordinary question, just as in English. This is illustrated in (89)-(90). (9ob) shows that adding a subjunctive plus an evidential to a rhetorical question results in rejection of the utterance.

(89) Context: Your daughter is complaining that learning how to cut fish is hard. You say:
a. tsun-tsi=lhkán=ha
$\mathrm{k}=\mathrm{wa}=\mathrm{S} \quad$ lil'q
say(DIR)-2SG.OBJ=1SG.INDIC $=$ YNQ DET $=I M P F=3$ POSS easy
'Did I tell you it would be easy?'

41 See Rocci 2007: 147 for the same claim for an Italian construction with similar semantics to
St'át'imcets conjectural questions. 
b. swat $\mathrm{ku}=$ tsút $\mathrm{k}=\mathrm{wa}=\mathrm{s} \quad$ lil'q

who DET=say DET=IMPF=3POss easy

'Who said it would be easy?'

(9o) Context: You are at the PNE (a fair) and there is this very scary ride which looks really dangerous. Your friend asks you if you are going to go on it. You say:
a. tsut-anwas=kácw=ha $\quad \mathrm{kw}=\mathrm{en}=\mathrm{klíisi}$
say-inside $=\mathbf{2 S G . I N D I C}=$ YNQ DET $=$ 1SG.POSS $=$ crazy
'Do you think I'm crazy?'
b. *tsut-anwas=ácw=ha=k'a $\quad \mathrm{kw}=\mathrm{en}=\mathrm{klíisi}$ say-inside $=2$ SG.SBJN $=$ YNQ $=\mathbf{I N F E R}$ DET $=1$ SG.POSS $=$ craZy
'Do you think I'm crazy?'

The status of speaker and addressee knowledge also differs between rhetorical questions and conjectural questions. In rhetorical questions, the speaker knows the true answer to the question, and typically assumes that the hearer does as well (e.g., Caponigro \& Sprouse 2007). Subjunctive questions are the exact opposite: neither the speaker nor the addressee typically knows the answer.

In the remainder of this section I will first present the analysis of conjectural questions which contain evidentials, and then explain an interesting difference between the evidential and the future with respect to subjunctive licensing.

First, we need an analysis of questions. I adopt a fairly standard approach, according to which a question denotes a set of propositions, each of which is a (partial, true or false) answer to the question (Hamblin 1973). ${ }^{42}$ This is illustrated in (91)-(92).

(91) $\llbracket$ does Hotze smoke $\rrbracket^{w}=\{$ that Hotze smokes, that Hotze does not smoke\}

(92) $\llbracket$ who left me this fish $\rrbracket^{w}=$ \{that Ryan left me this fish, that Meagan left me this fish, that Ileana left me this fish,... $\}=\{p: \exists x[p=$ that $x$ left me this fish]\}

42 As far as I am aware, this choice is not critical and a different approach to questions would work just as well. 
Cross-linguistic variation in modality systems: The role of mood

Next, we need an analysis for the inferential evidential $k$ 'a. I adopt Matthewson et al.'s (2007) and Rullmann et al.'s (2008) analysis of k'a as an epistemic modal with a presupposition about evidence source.

(93) $\llbracket k^{\prime} a(h)(g) \rrbracket^{c, w}$ is only defined if $h$ is a epistemic modal base, $g$ is a stereotypical ordering source, and for all worlds $w^{\prime}, \cap h\left(w^{\prime}\right)$ is the set of worlds in which the inferential evidence in w holds.

If defined, $\llbracket k^{\prime} a(h)(g) \rrbracket^{c, w}=$

$$
\lambda q_{\langle s, t\rangle} \cdot \forall w^{\prime} \in f_{c}\left(\max _{g(w)}(\cap h(w))\right)\left[q\left(w^{\prime}\right)=1\right]
$$

(adapted from Matthewson et al. 2007: 245)

I assume that the evidential modal scopes under the question operator, so that each proposition in the question denotation contains the evidential. A conjectural question thus bears some similarity to an English question containing a possibility modal (e.g., 'Could Bill have (possibly) arrived?'), with the additional factor that the evidential introduces a presupposition about evidence source. Following Guerzoni (2003), I assume that when a question contains a presupposition trigger, each proposition in the alternative set carries the relevant presupposition. The question therefore denotes a set of alternative partial propositions. This is illustrated in (94).43

$$
\begin{array}{lll}
\text { a. } & \text { t'iq=as=há=k'a } & \mathrm{k}=\text { Bill } \\
\text { arrive }=\mathbf{3 S B J N}=\mathbf{Y N Q}=\mathbf{I N F E R} & \text { DET=Bill }
\end{array}
$$

'I wonder if Bill arrived.'

b. Alternatives introduced by (94a):

\{that Bill possibly arrived [presupposing there is inferential evidence that Bill arrived], that Bill possibly did not arrive [presupposing there is inferential evidence that Bill did not arrive]\}

Notice that the evidence presuppositions of the two propositions in (94b) conflict with each other - there is presupposed to be evidence both that Bill did arrive, and that Bill did not arrive. As Guerzoni (2003) has shown for the presuppositions of English even, questions whose alternative propositions introduce different presuppositions end up presupposing the conjunction of all the individual presuppositions. Take, for example, the question in (95).

(95) Guess who even solved Problem 2?

43 Recall that although (94a) is translated into English using wonder, the meaning of (94a) does not include an attitude verb. The claim is that (94a) denotes a set of alternative propositions. 
This question introduces 'a set of alternative partial propositions that for each relevant person $x$ contains an answer asserting that $x$ solved Problem 2 and presupposing that solving problem 2 was less likely for $x$ than solving any other relevant problem' (Guerzoni 2003: 127). Guerzoni then observes that a speaker who utters (95)

knows that for any arbitrary individual in the restrictor of who, if the addressee answers that that individual solved the problem, he will automatically presuppose that the problem was difficult for that person. Moreover, if the speaker is unbiased, she doesn't know in advance (and has no expectations regarding) which propositions will be chosen by the addressee as the true answer to her question. Given this, it must be the case that she is taking for granted that the problem was hard for every arbitrary $x$ in the restrictor of who. Since the addressee will be able to infer this much, the question is a presupposition failure unless this condition is indeed satisfied in the context of the conversation (Guerzoni 2003: 128).

Applying this idea to the St'át'imcets conjectural questions, we obtain the result that an utterance of (94a) commits the speaker to the presupposition that there is evidence both that Bill did arrive, and that he did not. This is illustrated in (96).

(96) Alternatives introduced by (94a):

\{that Bill possibly arrived, that Bill possibly did not arrive\}

Presupposition of (94a):

There is inferential evidence both that Bill arrived and that Bill did not arrive

In previous work (Matthewson 2008a, Littell et al. 2009), I assumed that the mixed-evidence presuppositions which result when we conjoin the presuppositions of all the propositions in the question set could derive the reduced interrogative force of conjectural questions. The idea was that a speaker who utters a question while presupposing that there is mixed or even contradictory evidence about the true answer cannot be taken to be requiring that the hearer provide the true answer to the question. That is, the mixed presuppositions about evidence signal that the speaker does not 
Cross-linguistic variation in modality systems: The role of mood

believe the question is easily answerable, and this lets the hearer off the hook with respect to providing an answer. 44

However, there are various problems with this analysis, as pointed out by Littell (2009). One is that the evidence presuppositions are not always contradictory. For example, a conjectural question such as 'Who likes ice cream?' would presuppose for each contextually salient individual $x$ that there is inferential evidence that $x$ likes ice cream. But it is perfectly possible that everyone likes ice cream, and the evidence presuppositions in this case do not rule out the possibility that the hearer knows the true answer. A second problem is seemingly incorrect predictions about questions which contain other evidentials, such as reportative or direct evidentials. Littell argues that an analysis of conjectural questions which relies on conjoined evidence presuppositions should predict reduced interrogative force for any evidential question - yet cross-linguistically it is overwhelmingly only inferential or conjectural evidentials which result in reduced interrogative force. This is certainly true of St'át'imcets, as shown in the minimal pair in $(97) .45$

$$
\begin{aligned}
& \text { a. stám'=as=k'a ts7a } \\
& \text { what=3SBJN=INFER here } \\
& \text { 'I wonder what these are.' } \\
& \text { b. 'stám'=as=ku7 r ts7a } \\
& \text { what=3SBJN=REPORT here }
\end{aligned}
$$

For these reasons, I instead adopt and extend an analysis proposed by Littell (2009). Two assumptions are required. First, the evidence source

44 Rocci (2007) analyzes a construction in Italian with strikingly similar semantics and pragmatics: the che-subjunctive construction. According to Rocci, che-subjunctives, which are formed from questions, are interpreted as statements of doubt. He argues that they involve epistemic modality and inferential evidentiality, and induce the following presuppositions:

(i) $p$ is not in the Common Ground and $\neg p$ is not in the Common Ground

(ii) There is no sign that either Speaker or Hearer knows whether $p$ or $\neg p$

(iii) There is some set of facts $E$ in CG, such that $E$ is non-conclusive evidence in favor of $p$

These are very similar to the effects of the St'át'imcets conjectural questions. However, Rocci does not give a compositional analysis, perhaps partly because the che-subjunctives have no overt evidentials or epistemic modals in the structure.

45 Cheyenne is an exception; reportatives in questions in Cheyenne allow non-interrogative readings under certain circumstances (Murray to appear). 
requirement of an evidential in a question can or must undergo 'interrogative flip' (or 'origo shift'; Garrett 2001, Faller 2002, 2006, Aikhenvald 2006, Tenny \& Speas 2004, Tenny 2006, Davis, Potts \& Speas 2007, Murray to appear, among others). Thus, a question containing an evidential expects that the hearer, rather than the speaker, has the relevant type of evidence for the answer. For example, (98) is not appropriate if directed to your mother, if she is the one who always cooks dinner. However, it is acceptable when directed to a third person, who might have heard from your mother what you are going to eat.

(98) stám'=ku7 $\quad$ ku=cuz'=s-q'á7-lhkalh

what=REPORT DET=going.to=NOM-eat-1PL.POSS

'What are we going to eat?'

The second assumption is that a speaker who uses an evidential which is low on a hierarchy of evidence strength implicates that there is no available evidence of a stronger type (Faller 2002, among others). This also seems to be correct in St'át'imcets; the use of an inferential evidential, for example, leads a hearer to infer that the speaker did not have reportative or direct evidence. ${ }^{46}$

These two assumptions lead to the following result: a question containing an evidential which is low on the scale of evidence strength will lead to an implicature that the hearer does not have evidence of any stronger type. This is illustrated in (99).
a.
man'c-em=há=k'a
$\mathrm{k}=\mathrm{Hotze}$
smoke-MID $=$ YNQ $=$ INFER DET $=$ Hotze

'I wonder if Hotze smokes.'

b. Alternatives introduced by (99a):

\{that Hotze might smoke, that Hotze might not smoke\}

c. Presupposition of (99a):

The hearer has inferential evidence both that Hotze smokes and that Hotze does not smoke

46 Evidential hierarchies are a topic of some debate and there are many interesting questions to be investigated (see Faller 2002 for an overview). It is also an interesting question how evidence-type hierarchies interact with the variable interpretations of all evidentials in St'át'imcets (Matthewson et al. 2007, Rullmann et al. 2008). Although all strengths are possible for all evidentials in St'át'imcets, inferential $k$ ' $a$ is more likely to be weaker (i.e., to have a more restricted domain of worlds to quantify over), while the reportative $k u>$ and the perceived-evidence $=a n$ ' are much more likely to give rise to stronger interpretations. 
Cross-linguistic variation in modality systems: The role of mood

d. Implicature: The hearer does not have any stronger type of evidence than inferential about the correct answer

According to Littell (2009), this analysis accounts for the reduced interrogative force of conjectural questions. The idea is that inferential evidence is a fairly weak type of evidence, and a speaker who asks a question while implicating that the hearer only has inferential evidence about the true answer is letting the hearer off the hook with respect to answering. This is intended to account for (a) the judgments of St'át'imcets consultants that conjectural questions do not require an answer, (b) the fact that conjectural questions are infelicitous when the addressee is likely to know the answer (cf. (87)), and (c) the fact that conjectural questions are translated as 'I wonder' or 'maybe'-statements (although they do not literally have the semantics of 'wonder'). 'I wonder' is simply a typical method in English of raising a question without demanding an answer.

However, this account does not seem to predict a complete absence of interrogative force. After all, the inferential evidence the hearer is assumed to possess is better than no evidence at all. In line with this, an English question like 'According to the weak evidence you have, could Hotze smoke?' still functions pragmatically as an interrogative. I conclude, therefore, that interrogative flip plus implicatures about the absence of stronger evidence are not sufficient in and of themselves to completely let the hearer off the hook with respect to answering. This is actually a welcome result, since questions containing $k$ ' $a$ in the indicative mood are sometimes translated by speakers into English using ordinary questions (rather than as statements of doubt; see footnote 40). However, conjectural questions containing the subjunctive are never translated as ordinary questions. I therefore assume that while a question containing an evidential is already somewhat 'weakened' in terms of its interrogative force, the subjunctive performs a further weakening. The task now is to see whether this falls out from the analysis of the subjunctive proposed above.

Recall that in the context of a governing modal, the subjunctive adds the presupposition that in at least one of the best worlds in the modal base, the proposition is false. The best worlds here (as the modal is epistemic) are those which conform to the propositions known to be true, and in which things happen as normal. Since the evidential has undergone interrogative flip, the epistemically accessible worlds must also be flipped to be the worlds 
Lisa Matthewson

compatible with the hearer's knowledge. The results are shown in (100). ${ }^{47}$
(100)
a. cuz'=as=há=k'a ts7as s=Bill
going.to $=\mathbf{3 S B J N}=\mathbf{Y N Q}=\mathbf{I N F E R}$ come $\mathbf{N O M}=$ Bill
'I wonder if Bill is going to come.'
b. Alternatives introduced by (10oa):
that Bill is possibly going to come, that Bill is possibly not going to come\}
c. Presuppositions of (100a):
The hearer has inferential evidence both that Bill is going to come and that Bill is not going to come; Bill doesn't come in at least one normal world compatible with the hearer's knowledge, and Bill comes in at least one normal world compatible with the hearer's knowledge
d. Implicature: The hearer does not have any stronger type of evidence than inferential about the correct answer

As before, the implicature that the hearer does not have strong evidence about the true answer, combined with the mixed-evidence effect of the evidential presuppositions, will partially reduce the expectation that the hearer is able to answer the question. In addition, thanks to the subjunctive, the question now presupposes not only that the evidence about Bill's possible arrival is mixed, but also that there are worlds compatible with the hearer's knowledge in which Bill does come, and worlds compatible with the hearer's knowledge in which he does not come. In other words, the hearer does not know whether he will come or not. The result is that a subjunctive conjectural question has a significantly reduced expectation on the hearer to provide an answer. ${ }^{48}$

The account just given, which incorporates the analysis of the St'át'imcets subjunctive as weakening a modal proposition via domain restriction, suc-

47 An anonymous reviewer raises a potentially significant issue with the choice function required for these cases. With the deontic and imperative cases discussed above, the choice function had intuitive content (e.g., the 'very best way to achieve some end'), but here the role of the subjunctive is purely to make sure there are some 'best worlds' where the prejacent is false. It is thus not clear which proper subset of the best worlds the function picks out.

48 As noted above, conjectural questions also imply that the speaker does not know the answer. I assume that this follows, by Gricean reasoning, from the fact that the speaker uttered a question, rather than having simply asserted the true answer. However, there is a bit more to be said here, since plain questions in St'át'imcets allow a ‘display question' use - a teacher can ask (i): 
Cross-linguistic variation in modality systems: The role of mood

cessfully accounts for the distributional and interpretive facts illustrated in (84)-(85) above. The fact that the subjunctive requires a modal licenser in a question follows from the analysis of the subjunctive as requiring a governing modal. The fact that an evidential in a question always licenses at least slightly reduced interrogative force, regardless of mood, falls out from the fact that the evidential plays a part in reducing interrogative force. However, the added contribution of the subjunctive accounts for the preferred presence of the subjunctive in conjectural questions, as well as for the fact that questions containing an evidential plus the subjunctive, in contrast to indicative evidential questions, can only be interpreted with reduced interrogative force.

In the final part of this section I extend the discussion to conjectural questions which contain a future morpheme rather than an evidential. We have already seen some examples of this ((17b)-(18b) above). In contrast to the evidential $k^{\prime} a$, the future modal obligatorily requires the subjunctive mood if it is to be interpreted as a statement of doubt. This is shown in (101)-(102), where the (a) examples are only interpretable as ordinary questions which expect an answer.

$\begin{array}{lll}\text { (101) } \begin{array}{l}\text { t'íq=ha=kelh } \quad \mathrm{k}=\text { Bill } \\ \text { arrive=YNQ=FUT DET=Bill }\end{array} & \\ & \text { 'Is Bill going to come?' } & \text { FUT + INDIC } \\ \text { b. } & \begin{array}{l}\text { t'iq=as=há=kelh } \\ \text { arrive=3SBJN=YNQ=FUT DET=Bill } \\ \text { 'I wonder if Bill will come.' }\end{array} & \\ & & \text { FUT + SBJN }\end{array}$

(i) k’win ku=án'was múta7 án'was how.many DET=two and two

'What is two plus two?'

As an anonymous reviewer points out, this display use should technically remain even when the subjunctive is added. However, consultants judge the subjunctive version of (i) to no longer be a teacher's question, but a student's reply:

(ii) k’wín=as=k’a ku=án'was múta7 án'was how.many=3SBJN=INFER DET=two and two

'I don't know how much two plus two is.'

Perhaps conjectural questions like (ii) simply do not make good questions for a teacher to ask because they encode addressee ignorance. 
(102) a. inwat=wít=kelh

say. what $=3$ PL $=$ FUT

'What will they say?'

FUT + INDIC

b. inwat=wít=as=kelh

say. what $=3 \mathrm{PL}=3 \mathbf{S B J N}=\mathbf{F U T}$

'I wonder what they will say.'

FUT + SBJN

The contrast between the evidential and the future with respect to whether the subjunctive is required to create a conjectural question is striking. So far, I have argued that the evidential $k$ 'a contributes to reduced interrogative force by means of an implicature that the hearer has no better than inferential evidence for the true answer, and that the subjunctive contributes to further reduced interrogative force by presupposing that it is compatible with the hearer's knowledge state that each possible answer is false. Now unlike $k$ 'a, the future modal kelh has not been analyzed as an epistemic modal, and it does not introduce any evidence presuppositions. The denotation for kelh is given in (103).

(103) $\llbracket k e l h(h)(g) \rrbracket^{c, w, t}$ is only defined if $h$ is a circumstantial modal base and $g$ is a stereotypical ordering source.

If defined, $\llbracket k e l h(h)(g) \rrbracket^{c, w, t}=$

$\lambda q_{\langle s,\langle i, t\rangle\rangle} . \forall w^{\prime} \in f_{\mathcal{c}}\left(\max _{g(w)}(\cap h(w, t))\right)\left[\exists t^{\prime}\left[t<t^{\prime} \wedge q\left(w^{\prime}\right)\left(t^{\prime}\right)=1\right]\right]$

(adapted from Rullmann et al. 2008) 49

Applying this analysis of kelh to questions containing a subjunctive gives (104).

(104) a. nká7=as=kelh lh=cúz'=as nas $\mathrm{k}=$ Gloria

where $=3 \mathbf{S B J N}=$ FUT $\mathbf{C O M P}=$ going.to=2SG.SBJN go $\mathrm{DET}=$ Gloria

'I wonder where Gloria will go.'

b. Alternatives introduced by (104a):

\{that Gloria will go home, that Gloria will go to her mother's house, ...

49 I have altered Rullmann et al.'s formula to incorporate the ordering source and to make the format parallel to that of other formulas above. The modal base in (103) is a function from world-time pairs to sets of propositions. 
Cross-linguistic variation in modality systems: The role of mood

c. Presuppositions of (104a):

The future claim is made on the basis of the facts; Gloria won't go home in at least one stereotypical world compatible with the facts, Gloria will not go to her mother's house in at least one stereotypical world compatible with the facts, ...

There are no implicatures about evidence types this time, but interestingly, we still predict reduced interrogative force. And this time, the contribution of the subjunctive is absolutely critical to deriving the effect. Due to the subjunctive, the question as a whole presupposes for each contextually salient place that Gloria might go, that there is at least one stereotypical world compatible with the facts in which she doesn't go there. This means that the facts underdetermine where she might go - and thus, that the addressee may not know where she will go. Given that the subjunctive is crucial in deriving the reduced interrogative force, we correctly predict that the subjunctive is obligatory in conjectural questions like (102).

\subsection{Ignorance free relatives}

Ignorance free relatives in St'át'imcets are formed by the combination of a wh-word, the subjunctive, and the inferential evidential $k$ 'a. Some examples are repeated here..$^{50}$

(105) a. qwatsáts=t'u7 múta7 súxwast áku7, t’ak aylh áku7,

leave=PRT again go.downhill DEIC go then DEIC

nílh=k’a $\quad \mathrm{s}=$ npzán-as

FOC=INFER NOM=meet(DIR)-3ERG

k'a=lh=swát=as=k'a káti7 ku=npzán-as

INFER $=$ COMP $=$ who=3SBJN=INFER DEIC DET $=$ meet(DIR)-3ERG

'So he set off downhill again, went down, and then he met whoever he met.' (van Eijk \& Williams 1981: 66, cited in Davis 2009)

b. o, púpen'=lhkan [ta=stam'=as=á=k'a]

oh find $=1$ SG.INDIC [DET $=$ what $=3$ SBJN $=$ EXIS $=$ INFER]

'Oh, I've found something or other.'

(Unpublished story by "Bill” Edwards, cited in Davis 2009)

There is a large literature on free relatives, concentrating mainly on English (although see Dayal 1997 for discussion of Hindi and Davis 2009 for

50 Thanks to Henry Davis for helpful discussions of free relatives in St'át'imcets. 
discussion of St'át'imcets). Here I adopt von Fintel's (2000) analysis; as far as I know, nothing crucial hinges on the differences between von Fintel's analysis and those of, for example, Jacobson (1995) or Dayal (1997). I will argue that the St'át'imcets ignorance free relatives are compatible with von Fintel's proposals, and that their interpretation relies on the independently-attested semantics of the subjunctive and the evidential.

According to von Fintel, both ignorance and indifference free relatives presuppose that there is variation among the worlds in the modal base with respect to the identity of the referent. The free relative denotes a definite description, and the sentence as a whole asserts that the definite description satisfies the relevant property.

(106) (whatever) $(w)(F)(P)(Q)$

a. $\quad$ presupposes: $\forall w^{\prime} \in \min _{w}\left[F \cap\left(\lambda w^{\prime} . \iota x . P\left(w^{\prime}\right)(x) \neq \iota x . P(w)(x)\right)\right]$ : $Q\left(w^{\prime}\right)\left(\iota x . P\left(w^{\prime}\right)(x)\right)=Q(w)\left(\iota x . P\left(w^{\prime}\right)(x)\right)$

b. asserts: $Q(w)(\iota x . P(w)(x))$

(von Fintel 2000: 34)

With ignorance free relatives, the modal base $\mathrm{F}$ is the epistemic alternatives of the speaker. ${ }^{11}$ Consider (107), for example.

(107) There's a lot of garlic in whatever (it is that) Arlo is cooking.

(von Fintel 2000: 27)

(107) presupposes that in all the speaker's epistemically accessible worlds which are minimally different from the actual world and in which Arlo is cooking something different from what he is actually cooking, there is the same amount of garlic in what he is cooking. As the min-operator introduces an existential presupposition, (107) presupposes that there are epistemically accessible worlds in which Arlo is cooking something different from what he is actually cooking. This amounts to a presupposition that the speaker is ignorant about the identity of what Arlo is cooking. (107) then asserts that the unique thing which Arlo is cooking has a lot of garlic in it.

Turning to St'át'imcets, we see that von Fintel's semantics captures the required meanings accurately. (105a) presupposes that the speaker does not know who 'he' (the man being talked about) met, and asserts that he met whoever he met. Moreover, it seems that we can account for the presence of the subjunctive in free relatives, and also for the presence of the inferential evidential. In particular, I would like to suggest that the presupposition of

51 With indifference free relatives, the modal base includes counterfactual alternatives. 
Cross-linguistic variation in modality systems: The role of mood

speaker ignorance about the denotation of the free relative actually derives from the evidential $k^{\prime} a$ and the subjunctive.

The basic idea is that an ignorance free relative is formed from a conjectural question (see Davis 2009 for this insight, although Davis does not word it in this way). The free relative in (105a), for example, is formed from the conjectural question in (108).

$$
\begin{array}{ll}
\text { swát=as=k’a } & \text { káti7 ku=npzán-as } \\
\text { who=3SBJN=INFER DEIC } & \text { DET=meet(DIR)-3ERG }
\end{array}
$$

'I wonder who he met.'

Following the analysis of conjectural questions given in subsection 7.2, (108) denotes the set of propositions of the form 'he met x'. The evidential in (108) would normally undergo interrogative flip, giving rise to the inference that the hearer is not in a position to answer the question of who he met. When (108) is embedded in a non-matrix environment as in (105a), however, I assume that interrogative flip does not take place. The free relative based on (108) will therefore carry a conjoined presupposition that the speaker has inferential evidence for each alternative, and an implicature that the speaker has no stronger evidence about who he met. And due to the subjunctive, it will presuppose that for each alternative, there is at least one best world in the modal base in which that alternative is false. Thus, the free relative formed from (108) will presuppose that there is mixed evidence about who he met, and that for each person $x$, it's compatible with the speaker's knowledge that he did not meet $\mathrm{x}$. This derives the desired 'speaker ignorance' presupposition. Moreover, we can regard the subjunctive as an overt spell-out of the existential presupposition of the min-operator, namely that there are epistemically accessible worlds in which the person he met is not who he met in the actual world.

A final advantage of this approach is that we correctly capture the fact that the modal base contains epistemic alternatives, as $k$ 'a lexically encodes an epistemic conversational background. This accounts for the fact that only ignorance free relatives, and not indifference free relatives, contain $k$ ' $a$ in St'át'imcets (Davis 2009). ${ }^{52}$

52 Free relatives in St'át'imcets are far from solved. For example, Davis (2009) points out a problem with free relatives which surface as DPs, as in (105b) above. Davis shows that syntactically, this $w h$-word acts like the head noun of a relative clause. This poses a challenge for the claim that (105b) is formed from a conjectural question. Moreover, if the wh-word is functioning as a head noun in (105b), the evidential k'a should not be able to attach to it, as 
Lisa Matthewson

\section{4 'Pretend'}

There are two patterns to account for with the 'pretend' cases, depending on the dialect. In Upper St'át'imcets, the subjunctive plus the normative modal $k a$ frequently renders a 'pretend to be ...' interpretation. In Whitley et al. no date, a native-speaker-produced St'át'imcets teaching manual, the standard construction when the teacher is asking the students to pretend something is that in (109).

(109) a. skalúl7=acw=ka: saq'w knáti7 múta7 em7ímn-em

owl=2SG.SBJN=DEON fly DEIC and animal.noise-MID

'Pretend to be an owl: fly around and hoot.' (Davis 2006: chapter 24)

b. snu=hás=ka ku-skícza7

2SG.EMPH=3SBJN=DEON DET=mother

'Pretend to be the mother.' $\quad$ (Whitley et al. no date)

In Lower St'át'imcets, however, examples like the ones in (109) are rejected in 'pretend' contexts. Lower St'át'imcets uses either an emphatic pronoun in a cleft, as in (110a), or the adhortative particle malh, as in (110b). In each case, the subjunctive is present, but $k a$ is absent.

$$
\begin{array}{ll}
\text { a. } & \text { nu=hás } \quad k u=\text { skalúla7: sáq'w=kacw knáti7 } \\
\text { 2SG.EMPH=3SBJN DET=owl } & \text { fly=2SG.INDIC DEIC }
\end{array}
$$

'Pretend to be an owl.'

b. skalúl7=acw=malh: $\quad$ sáq'w=kacw knáti7

OWl=2SG.SBJN=ADHORT fly=2SG.INDIC DEIC

'Pretend to be an owl: fly around.'

In each of the dialectal variants, the apparent 'pretend' construction seems to reduce to another usage, rather than really meaning 'pretend'. The examples in (109) are merely instances of the subjunctive adding to a normative modal assertion. (109a) thus really means something like 'I wish you were an owl', and (109b) means 'I wish you were the mother.' In (110a), the subjunctive adds to a plain assertion to create a wish, something which is possible with clefts; cf. (5) above. As for (110b), the consultant spontaneously

k'a attaches only to predicates. This is a peculiarity of k'a; Davis shows that other secondposition evidentials, such as reportative $k u 7$ or perceived-evidence $=a n$ ', are ungrammatical in free relatives. Further research is required. 
Cross-linguistic variation in modality systems: The role of mood

translates this into English as 'You may as well be an owl'. The presence of adhortative malh here is a matter for future research; see comments in Section 8 below.

Support for the idea that (109) and (110) are not really 'pretend' constructions comes from the fact that exactly parallel structures are used when the wish is not that someone pretend to be something, but rather is a wish which has a chance of coming true. This is shown in (111). While the consultant accepts a 'pretend' translation for the sentences in (111), she spontaneously translates them into English using simply 'you be ...'. She judges that the St'át'imcets sentences do not really mean 'pretend'.

\begin{tabular}{|c|c|c|}
\hline \multirow[t]{3}{*}{ (111) a. } & nu=hás $\quad \mathrm{ku}=\mathrm{kúkwpi7}$ & \\
\hline & 2SG.EMPH=3SBJN DET=chief & \\
\hline & $\begin{array}{l}\text { 'Pretend to be the chief.' } \\
\text { 'You be the chief.' }\end{array}$ & $\begin{array}{r}\text { [accepted] } \\
\text { [spontaneously given] }\end{array}$ \\
\hline \multirow[t]{2}{*}{ b. } & $\begin{array}{ll}\text { nu=hás } & \mathrm{ku}=\mathrm{kúkw} \\
\text { 2SG.EMPH=3SBJN } & \text { DET=cook }\end{array}$ & \\
\hline & $\begin{array}{l}\text { 'Pretend to cook.' } \\
\text { 'You be the cook.' }\end{array}$ & $\begin{array}{r}\text { [accepted] } \\
\text { [spontaneously given] }\end{array}$ \\
\hline
\end{tabular}

\subsection{Why St'át'imcets is not like Romance}

In this final sub-section I return to a major cross-linguistic difference between the St'át'imcets subjunctive and more familiar, Indo-European subjunctives, namely that in St'át'imcets the subjunctive is never selected by a matrix predicate, and in fact is ungrammatical under all attitude verbs (as shown in (38) above).

It turns out that this falls out from the current analysis. The St'át'imcets subjunctive is parasitic on a modal, and introduces the presupposition that in at least one of the best worlds in the modal base according to the ordering source, the embedded proposition is false. This presupposition is incompatible with the semantics of attitude verbs, which are standardly analyzed as introducing universal quantification over a set of worlds. This is illustrated in (112) for English believe.

$$
\begin{aligned}
& \llbracket \text { believe } \rrbracket^{w, g}= \\
& \lambda p_{\langle s, t\rangle} \cdot \lambda x . \forall w^{\prime} \text { compatible with what } x \text { believes in } w: p\left(w^{\prime}\right)=1 \\
& \text { (von Fintel \& Heim 2007: 18) }
\end{aligned}
$$


There is no reason to assume that attitude verbs like 'believe' have different semantics in St'át'imcets from in English. On the contrary, the St'át'imcets verb tsutánwas 'think, believe' must involve universal quantification over belief-worlds, without the possibility of domain restriction (in other words, there is no choice function or second ordering source). Thus, (113), just like its English gloss, requires that in all Laura's belief-worlds, John has left. It cannot mean that Laura's beliefs allow, but do not require, that John has left.

(113) tsut-ánwas $\mathrm{k}=$ Laura $\quad \mathrm{kw}=\mathrm{s}=$ qwatsáts $=\mathrm{s} \quad \mathrm{k}=\mathrm{John}$

say-inside DET $=$ Laura DET $=$ NOM=leave $=3$ POSS DET $=$ John

'Laura thinks that John left.'

Given this, adding the subjunctive under the verb 'believe' in St'át'imcets leads to the following contradictory result.

$\begin{array}{lll}\text { *tsut-ánwas } \mathrm{k}=\text { Laura } & \mathrm{kW}=\mathrm{S}=\mathrm{qwatsáts=as} \quad \mathrm{k}=\mathrm{John} \\ \text { say-inside } & \mathrm{DET}=\mathrm{Laura} \\ \mathrm{DET}=\mathrm{NOM}=\text { leave=3SBJN } & \mathrm{DET}=\mathrm{John}\end{array}$

'Laura thinks that John left.'

$\llbracket(114) \rrbracket^{w}$ is only defined if $\exists w^{\prime}$ compatible with Laura's beliefs in $w$ : John didn't leave in $w^{\prime}$

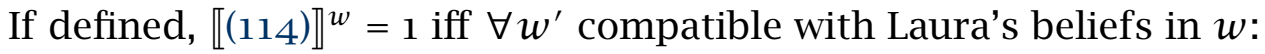
John left in $w^{\prime}$

The presupposition of the subjunctive contradicts the assertion. This explains why the subjunctive is not used under verbs like 'believe' in St'át'imcets, unlike in Romance.

We need to separately discuss the absence of subjunctive under desire verbs in St'át'imcets. An example was given in (38e), repeated here. ${ }^{53}$

(115) xát'-min'-as $\mathrm{k}=$ Laura $\quad \mathrm{kw}=\mathrm{s}=\mathrm{t}^{\prime} \mathrm{iq}=\varnothing \quad \mathrm{k}=\mathrm{J}$ ohn want-RED-3ERG DET=Laura DET=NOM=arrive=3INDIC DET=John

'Laura wanted John to come.'

Desire verbs are often treated as involving comparison between alternative worlds (e.g., Stalnaker 1984, Heim 1992 and much subsequent work). The intuition is that 'John wants you to leave means that John thinks that if you leave he will be in a more desirable world than if you don't leave' (Heim 1992:

53 Thanks to an anonymous reviewer for discussion of this issue. 
Cross-linguistic variation in modality systems: The role of mood

193). Here I adopt Portner's (1997) analysis of desire verbs, and in particular we will see that the St'át'imcets verb xát'min' is better analyzed as similar to English hope (which according to Portner is similar to believe, and therefore is not intrinsically comparative) than to English want.

Portner analyzes hope in terms of a buletic accessibility relation $\operatorname{Bul}_{\alpha}(s, b)$. For any situation $s$ and belief situation $b$ of an agent $\alpha, \operatorname{Bul}_{\alpha}(s, b)$ is the set of buletic alternatives for $\alpha$ in $s$ - i.e., 'the worlds in which the most of $\alpha$ 's plans in $s$ (relative to his or her beliefs in $b$ ) are carried out' (Portner 1997: 178). The sentence in (116) receives the interpretation shown: it is true just in case in all of James's buletic alternatives, Joan arrives in Richmond soon.

(116) James hopes that Joan arrives in Richmond soon.

$\left\{s: \operatorname{Bul}_{\text {James }}(s, b) \subseteq \llbracket\right.$ Joan arrives in Richmond soon $\left.\rrbracket^{s}\right\}$

(Portner 1997: 188)

Portner's analysis of hope differs from that of want, and is parallel to that of believe, in crucial respects (which explain the different embedding possibilities for hope/believe vs. want). In particular, while hope and believe are defined directly in terms of (doxastic or buletic) alternatives, want is defined in terms of the agent's plans. Portner argues that the difference between hope and want is 'an idiosyncratic lexical one' (Portner 1997: 189). If this is correct, it would not be unexpected that a language could contain only the hope-type of desire predicate.

If we apply Portner's analysis of hope to St'át'imcets xát'min', and attempt to use the subjunctive in the embedded clause, we get the result in (117).

$$
\begin{array}{llll}
\text { *xát'-min'-as } & \mathrm{k}=\text { Laura } & \mathrm{kw}=\mathrm{s}=\mathrm{t} \text { 'íq=as } & \mathrm{k}=\mathrm{John} \\
\text { want-RED-3ERG } & \text { DET=Laura } & \mathrm{DET}=\mathrm{NOM}=\text { arrive=3SBJN } & \text { DET=John }
\end{array}
$$

'Laura wanted John to come.'

$\llbracket(117) \rrbracket^{s}$ is only defined if $\exists s \in \operatorname{Bul}_{\text {Laura }}(s, b):$ John does not come in $s$

If defined, $\llbracket(117) \rrbracket^{s}=1$ iff $\left\{s: \operatorname{Bul}_{\text {Laura }}(s, b) \subseteq \llbracket\right.$ John comes $\left.\rrbracket^{s}\right\}$

(117) is defined only if there is at least one situation in Laura's buletic alternatives in which John does not come, but it asserts that in all Laura's buletic alternatives, John comes. The contradiction between the presupposition and the assertion leads to the unacceptability of the sentence. 
The idea that St'át'imcets xát'min' is parallel to English hope or believe rather than to English want leads to the following cross-linguistic comparison. While Indo-European has two kinds of attitude verbs - those involving universal quantification over alternative worlds, and those which are intrinsically comparative - St'át'imcets has only the former kind. This explains why St'át'imcets lacks subjunctives under attitude verbs, and even allows us to draw the broader generalization that St'át'imcets only allows universal quantification over worlds. This language lacks both true possibility modals and comparative subjunctive-embedding predicates. ${ }^{54}$

\section{Conclusions and questions for future research}

The goal of this paper was to extend the formal cross-linguistic study of modality to the related domain of mood. Prior work on St'át'imcets has proposed that languages vary in whether their modals encode quantificational force (as in English), or conversational background (as in St'át'imcets) (Matthewson et al. 2007, Rullmann et al. 2008, Davis et al. 2009). Here, I have argued that languages vary in their mood systems along the same dimension, at least functionally. While some languages use moods to encode distinctions of conversational background (buletic, deontic, etc.), St'át'imcets uses mood to functionally achieve a restriction on modal quantificational force. (Of course technically, both modals and moods in St'át'imcets restrict conversational backgrounds: the modal force is always universal.) If this view is correct, then each language-type draws on its moods and its modals together to allow the full range of specifications. In other words, what modals don't encode, moods do. The simplified typological table is repeated here.

\begin{tabular}{lll} 
& $\begin{array}{l}\text { LEXICALLY ENCODE } \\
\text { QUANT. FORCE }\end{array}$ & $\begin{array}{l}\text { LEXICALLY ENCODE } \\
\text { CONV. BACKGROUND }\end{array}$ \\
\hline $\begin{array}{l}\text { Indo-European } \\
\text { St'át'imcets }\end{array}$ & $\begin{array}{l}\text { modals } \\
\text { moods }\end{array}$ & $\begin{array}{l}\text { moods } \\
\text { modals }\end{array}$
\end{tabular}

Table $5 \quad$ Modal and mood systems

The analysis presented here raises some questions for future research. One outstanding issue is the status of subjunctives with no overt licenser at 54 Thanks to an anonymous reviewer for discussion of this point. 
Cross-linguistic variation in modality systems: The role of mood

all, as in (5)-(6). As noted earlier, these appear to be productive only in clefts. It is not immediately obvious that a cleft contains a modal operator which would license the subjunctive, so further investigation is required (although see fn. 22).

A second interesting puzzle relates to subjunctive imperatives (see subsection 7.1). These seem to strongly prefer the presence of the adhortative particle malh, which is normally optional in imperatives. Perhaps malh (which has not previously been analyzed) is a modal, and perhaps its obligatoriness reflects the licensing requirement of the subjunctive. But what consequence would this have for the analysis provided above, which assumes that even imperatives with no adhortative particle contain a concealed deontic modal? This question cannot be answered without a real investigation of malh, something which goes beyond the bounds of the current paper.

An even trickier element is the particle t'u7. t'uz is the culprit in the two uses of the subjunctive I have declined to analyze here, the 'might as well' cases and the indifference free relatives. Like malh, t'u has not yet been formally analyzed, but for t'uz there are not even any clear descriptive generalizations about its usage. It is often translated as 'just' or 'still', but also occurs where there is no obvious English translation, or even any detectable semantic contribution. t'u frequently appears with strong quantifiers, as in (118a), is almost obligatory if one wants to express 'only', as in (118b), and is also the St'át'imcets way to express 'but', as in (118c) (although here, unlike in its other uses, it is not a second-position enclitic, and this may therefore be a case of homophony).

a. tákem=t'u7 swat áolsvm l=ti=tsítcw=a
all=PRT who sick in=DET=house=EXIS

'Everyone in the house was sick.'

(Matthewson 2005: 311)

b. tsúkw=t'u7 snilh ti=tsícw=a aolsvm-áolhcw

finish=PRT 3SG.EMPH DET=get.there=EXIS sick-house

'It was only him who went to the hospital.' (Matthewson 2005: 324)

c. plan aylh láku7 wa7 cw7it i=tsetsítcw=a, t'u7 already then DEIC IMPF many DET.PL=houses=EXIS but pináni7 cw7aoz láti7 ku=wá7 tsitcw TEMP.DEIC NEG DEIC DET=IMPF house

'Now there are lots of houses there, but then there were no houses.' 
As noted above, t'u is present in the 'might as well' uses of the subjunctive, and in indifference free relatives. Examples are repeated here.

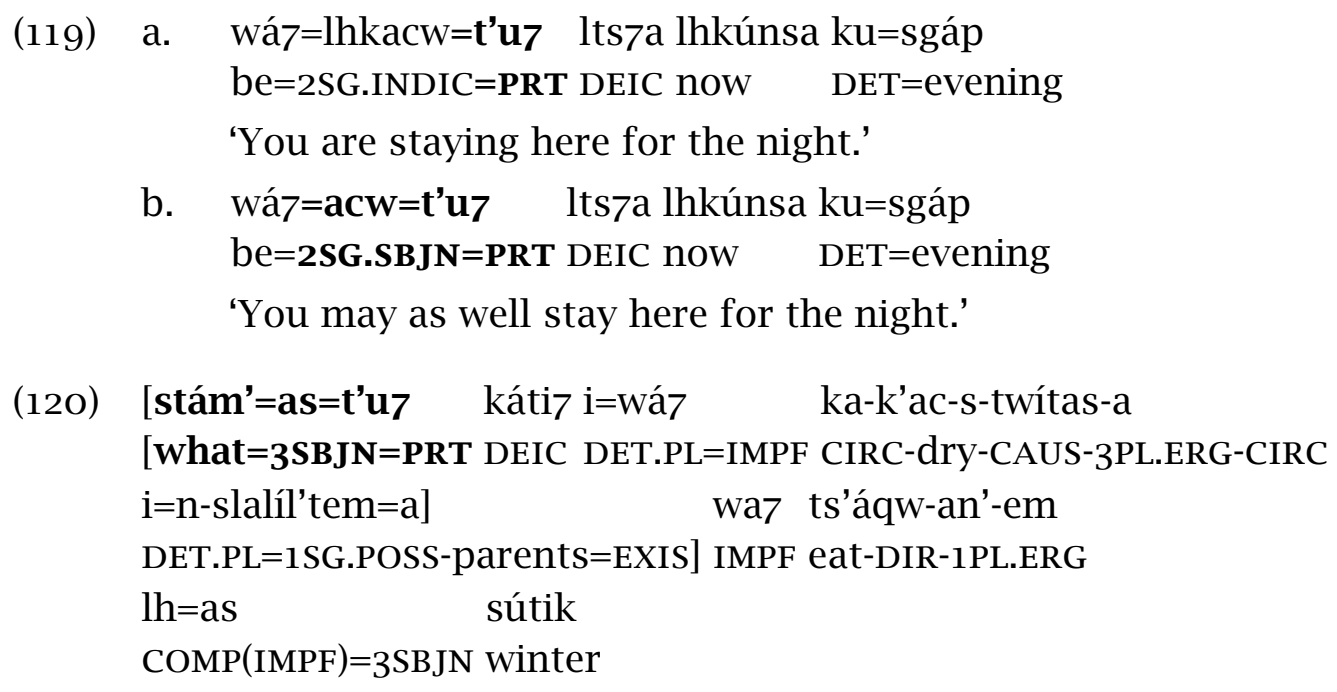

(Matthewson 2005: 141, cited in Davis 2009)

Given the analysis above, we expect there to be a modal - or at least a modal base and an ordering source - present in any structure where the subjunctive is licensed. The interpretation of subjunctive + t'u in (119b) is plausibly modal - the consultants are remarkably consistent with the 'might as well' translation. There is also a certain similarity between the 'might as well' construction and the Sufficiency Modal Construction (Krasikova \& Zchechev 2005, von Fintel \& Iatridou 2008), illustrated in (121).

(121) To get good cheese, you only have to go to the North End!

(von Fintel \& Iatridou 2008: 445)

The crucial elements of the Sufficiency Modal Construction are (a) a necessity modal and (b) an exclusive operator such as 'only'. ${ }^{55}$ The possible connection between (119) and (121) may be fruitful to investigate in future work. ${ }^{56}$

55 For von Fintel and Iatridou, the 'only' is decomposed into 'NEG ... except' (and shows up overtly as this in some languages).

56 See also Mitchell 2003 on 'might as well' in English. 
Cross-linguistic variation in modality systems: The role of mood

As for indifference free relatives as in (120), these also very plausibly contain a covert modal, presumably a necessity one. The important question will be whether the subjunctive can be analyzed as a weakener in the indifference free relatives. Ideally, the future analysis of (119)-(120) will also elucidate the semantic connection between the two t'u7-subjunctives, both of which somehow express the notion of 'indifference' (although perhaps in different senses of the word). (119b), for example, conveys that you can stay here for the night or not, I don't really care.

In spite of these outstanding questions, I believe that the empirical coverage of the analysis presented here is encouraging. Out of the nine meaningful uses of the St'át'imcets subjunctive, we set aside two which rely on the poorlyunderstood particle t'u7, but have managed to unify the remaining seven. The analysis accounts for such seemingly disparate effects as the weakening of imperatives, the reduction in interrogative force of questions, and the non-appearance of the subjunctive under any attitude verb. The analysis, if correct, supports the modal approach to mood advocated by Portner (1997), and suggests that languages have a certain amount of freedom in how they divide up the various functional tasks required of moods and modals.

Finally, the research reported on here opens up broader questions about the nature of mood cross-linguistically, for example about the relation between subjunctive and irrealis. In Section 2, I showed that the St'át'imcets subjunctive patterns morpho-syntactically, as well as in some of its semantic properties, like a subjunctive rather than an irrealis. However, we also saw that the St'át'imcets subjunctive differs semantically from Indo-European subjunctives. I argued above (see fn. 9) that the use of the term 'subjunctive' was justified, even in the face of such non-trivial cross-linguistic variation. However, there is much more work to be done on the formal semantics of mood cross-linguistically. Once a wider range of systems are investigated in depth, we may find that the traditional terminology does not correlate with the cross-linguistically interesting divisions. Topics for future inquiry include whether there is a minimal semantic change which would turn a subjunctive morpheme into an irrealis one, or vice versa, and in general what the semantic building blocks are from which moods are composed. 
Lisa Matthewson

\section{References}

Aikhenvald, Alexandra. 2006. Evidentiality. New York: Oxford University Press.

Baker, Mark \& Lisa Travis. 1997. Mood as verbal definiteness in a "tenseless" language. Natural Language Semantics 5(3). 213-269. doi:10.1023/A:1008262802401.

Beghelli, Filippo. 1998. Mood and the interpretation of indefinites. The Linguistic Review 15(2-3). 277-300. doi:10.1515/tlir.1998.15.2-3.277.

Bolinger, Dwight. 1968. Postposed main phrases: an English rule for the Romance subjunctive. Canadian Journal of Linguistics 14. 3-33.

Caponigro, Ivano \& Jon Sprouse. 2007. Rhetorical questions as questions. In Proceedings of Sinn und Bedeutung 11, 121-133. http://idiom.ucsd.edu/ ivano/Papers/2007_Rhetorical-Qs_SuB.pdf.

Condoravdi, Cleo. 2002. Temporal interpretation of modals: Modals for the present and the past. In David Beaver, Stefan Kaufmann, Brady Clark \& Luis Casillas (eds.), Stanford Papers on Semantics, vol. 7, 59-88. Stanford: CSLI Publications. http://semanticsarchive.net/Archive/2JmZTIwO/.

Davis, Christopher, Christopher Potts \& Margaret Speas. 2007. The pragmatic values of evidential sentences. In Masayuki Gibson \& Tova Friedman (eds.), Proceedings of the 17th Conference on Semantics and Linguistic Theory, 71-88. Ithaca, NY: CLC Publications. doi:1813/11294.

Davis, Henry. 200o. Remarks on Proto-Salish subject inflection. International Journal of American Linguistics 66(4). 499-520. doi:10.1086/466439.

Davis, Henry. 2006. A grammar of Upper St'át'imcets. Ms., University of British Columbia.

Davis, Henry. 2009. Free relatives in St'át'imcets (Lillooet Salish). Ms., University of British Columbia.

Davis, Henry, Lisa Matthewson \& Hotze Rullmann. 2009. 'Out of control' marking as circumstantial modality in St'át'imcets. In Lotte Hogeweg, Helen de Hoop \& Andrey Malchukov (eds.), Cross-linguistic semantics of tense, aspect and modality, 205-244. Oxford: John Benjamins. http:// www.linguistics.ubc.ca/sites/default/files/TamTam_final_11-o8-o8.pdf.

Dayal, Veneeta. 1997. Free relatives and ever: Identity and free choice readings. In Proceedings of SALT VII, 99-116. http://www.rci.rutgers.edu/ $\sim$ dayal/ever.pdf.

van Eijk, Jan. 1997. The Lillooet language: Phonology, morphology, syntax. Vancouver, BC: UBC Press. 
Cross-linguistic variation in modality systems: The role of mood

van Eijk, Jan \& Lorna Williams. 1981. Lillooet legends and stories. Mt. Currie, BC: Ts'zil Publishing House.

Faller, Martina. 2002. Semantics and pragmatics of evidentials in Cuzco Quechua: Stanford dissertation.

Faller, Martina. 2006. Evidentiality and epistemic modality at the semantics/pragmatics interface. http://www.eecs.umich.edu/ rthomaso/ lpwo6/fallerpaper.pdf.

Farkas, Donka. 1992. On the semantics of subjunctive complements. In Paul Hirschbühler \& Konrad Koerner (eds.), Romance languages and modern linguistic theory: Papers from the 2oth linguistic symposium on Romance languages, 69-104. Amsterdam and Philadelphia: Benjamins.

Farkas, Donka. 2003. Assertion, belief and mood choice. Paper presented at the Workshop on Conditional and Unconditional Modality, ESSLLI, Vienna. http://people.ucsc.edu/ farkas/papers/mood.pdf.

von Fintel, Kai. 200o. Whatever. In Proceedings of SALT X, 27-40. http: //web.mit.edu/fintel/www/whatever.pdf.

von Fintel, Kai \& Anthony Gillies. 2010. Must ... stay ... strong! Natural Language Semantics. doi:10.1007/s11050-010-9058-2.

von Fintel, Kai \& Irene Heim. 2007. Intensional semantics lecture notes. Ms., MIT. http://mit.edu/fintel/IntensionalSemantics.pdf.

von Fintel, Kai \& Sabine Iatridou. 2008. How to say ought in foreign: The composition of weak necessity modals. In Jacqueline Guéron \& Jacqueline Lecarme (eds.), Time and modality, 115-141. Dordrecht: Springer. http: //mit.edu/fintel/fintel-iatridou-20o6-ought.pdf.

Garrett, Edward. 2001. Evidentiality and assertion in Tibetan. Los Angeles, CA: UCLA dissertation.

Gauker, Christopher. 1998. What is a context of utterance? Philosophical Studies 91(2). 149-172. doi:10.1023/A:1004247202476.

Giannakidou, Anastasia. 1997. The landscape of polarity items. Groningen: University of Groningen dissertation.

Giannakidou, Anastasia. 1998. Polarity sensitivity as (non)veridical dependency. Amsterdam and Philadelphia: John Benjamins.

Giannakidou, Anastasia. 2009. The dependency of the subjunctive revisited: Temporal semantics and polarity. Lingua 119(12). 1883-1908. doi:10.1016/j.lingua.2008.11.007.

Giorgi, Alessandra \& Fabio Pianesi. 1997. Tense and aspect: From semantics to morpho-syntax. Oxford: Oxford University Press.

Guerzoni, Elena. 2003. Why 'even' ask? on the pragmatics of questions and 
the semantics of answers: MIT dissertation. http://hdl.handle.net/1721.1/ 17646.

Hamblin, C. L. 1973. Questions in Montague English. Foundations of Language 10(1). 45-53. http://www.jstor.org/stable/25000703.

Han, Chung-hye. 1997. Deontic modality of imperatives. Language and Information 1. 107-136.

Han, Chung-hye. 1999. Deontic modality, lexical aspect and the semantics of imperatives. In Linguistics in the morning calm 4, Seoul: Hanshin Publications. URLhttp://www.sfu.ca/ chunghye/papers/morningcalm. pdf.

Han, Chung-hye. 2002. Interpreting interrogatives as rhetorical questions. Lingua 112(3). 201-229. doi:10.1016/Soo24-3841(01)0o044-4.

Haverkate, Henk. 2002. The syntax, semantics and pragmatics of Spanish mood. Amsterdam and Philadelphia: John Benjamins.

Heim, Irene. 1992. Presupposition projection and the semantics of attitude verbs. Journal of Semantics 9(3). 183-221. doi:10.1093/jos/9.3.183.

Hooper, Joan B. 1975. On assertive predicates. In John Kimball (ed.), Syntax and semantics 4, 91-124. New York: Academic Press.

Jacobs, Peter. 1992. Subordinate clauses in Squamish: A Coast Salish language. MA thesis, University of Oregon.

Jacobson, Pauline. 1995. On the quantificational force of English free relatives. In Emmon Bach, Eloise Jelinek, Angelika Kratzer \& Barbara Partee (eds.), Quantification in natural language, 451-486. Dordrecht: Kluwer.

James, Frances. 1986. Semantics of the English subjunctive. Vancouver, BC: UBC Press.

Klein, Flora. 1975. Pragmatic constraints in distribution: the Spanish subjunctive. In Papers from the 11th CLS, 353-365.

Krasikova, Sveta \& Ventsislave Zchechev. 2005. Scalar uses of only in conditionals. In Proceedings of the fifteenth Amsterdam Colloquium, 137142. University of Amsterdam. http:www.ventsislavzhechev.eu/Home/ Publications_files/.

Kratzer, Angelika. 1981. The notional category of modality. In Hans-Jürgen Eikmeyer \& Hannes Rieser (eds.), Words, worlds, and contexts: New approaches in word semantics (Research in Text Theory 6), 38-74. Berlin: de Gruyter.

Kratzer, Angelika. 1991. Modality. In Dieter Wunderlich \& Arnim von Stechow (eds.), Semantics: An international handbook of contemporary research, 639-650. Berlin: de Gruyter. 
Cross-linguistic variation in modality systems: The role of mood

Kratzer, Angelika. 2009. Modals and conditionals again, chapter 3. To be published by Oxford University Press.

Kroeber, Paul. 1999. The Salish language family: Reconstructing syntax. Lincoln, NE: The University of Nebraska Press. doi:10.1017/Soo22226702231928.

Littell, Patrick. 2009. Conjectural questions and the wonder effect or: What could conjectural questions possibly be? Ms, University of British Columbia.

Littell, Patrick, Lisa Matthewson \& Tyler Peterson. 2009. On the semantics of conjectural questions. Paper presented at the MOSAIC Workshop (Meeting of Semanticists Active in Canada), Ottawa.

Lunn, Patricia. 1995. The evaluative function of the Spanish subjunctive. In Joan Bybee \& Suzanne Fleischman (eds.), Modality and grammar in discourse, 419-449. Amsterdam and Philadelphia: Benjamins.

Matthewson, Lisa. 1998. Determiner systems and quantificational strategies: Evidence from Salish. The Hague: Holland Academic Graphics.

Matthewson, Lisa. 1999. On the interpretation of wide-scope indefinites. Natural Language Semantics 7(1). 79-134. doi:10.1023/A:1008376601708.

Matthewson, Lisa. 2005. When I was small - $i$ wan kwikws: Grammatical analysis of St'át'imcets oral narratives. Vancouver, BC: UBC Press.

Matthewson, Lisa. 2006. Presuppositions and cross-linguistic variation. In Proceedings of NELS 36, Amherst, Mass: GLSA Publications.

Matthewson, Lisa. 2008a. Moods vs. modals in St'át'imcets and beyond. Paper presented at New York University.

Matthewson, Lisa. 2008b. Pronouns, presuppositions and semantic variation. In Proceedings of SALT XVIII, 527-550. Cornell University: CLC Publications. http://www.linguistics.ubc.ca/sites/default/files/ MatthewsonSALTpronouns.pdf.

Matthewson, Lisa. 2010. Evidence about evidentials: Where fieldwork meets theory. Paper presented at Linguistic Evidence 2010, University of Tübingen. http://www.linguistics.ubc.ca/sites/default/files/ MatthewsonLE2010.pdf.

Matthewson, Lisa. to appear. On apparently non-modal evidentials. To appear in Proceedings of CSSP 2009 (EISS8).

Matthewson, Lisa, Hotze Rullmann \& Henry Davis. 2007. Evidentials as epistemic modals: Evidence from St'át'imcets. In J.V. Craenenbroeck (ed.), Linguistic Variation Yearbook, vol. 7, 201-254. John Benjamins Publishing Company. 
Mitchell, Keith. 2003. Had better and might as well: On the margins of modality? In M. Krug R. Facchinetti \& F. Palmer (eds.), Modality in contemporary english, 129-149. Berlin: Mouton de Gruyter.

Murray, Sarah. to appear. Evidentiality and questions in Cheyenne. In Suzi Lima (ed.), Proceedings of SULA 5: Semantics of under-represented languages in the Americas, Amherst, MA: GLSA Publications.

Palmer, Frank. 2006. Mood and modality. Cambridge: Cambridge University Press 2nd edn. doi:10.2277/0521804795.

Panzeri, Francesca. 2003. In the (indicative or subjunctive) mood. In Proceedings of Sinn und Bedeutung 7, http://ling.uni-konstanz.de/pages/ conferences/sub7/proceedings/download/sub7_panzeri.pdf.

Peterson, Tyler. 2009. The ordering source and graded modality in Gitskan epistemic modals. Ms., University of British Columbia. http://www. linguistics.ubc.ca/sites/default/files/Peterson(SuB).pdf.

Peterson, Tyler. 2010. Epistemic modality and evidentiality in Gitksan at the semantics-pragmatics interface: University of British Columbia dissertation. http://hdl.handle.net/2429/23596.

Portner, Paul. 1997. The semantics of mood, complementation and conversational force. Natural Language Semantics 5(2). 167-212. doi:10.1023/A:1008280630142.

Portner, Paul. 2003. The semantics of mood. In Lisa Cheng \& Rint Sybesma (eds.), The second Glot international state-of-the-article book, 47-77. Berlin: Mouton de Gruyter.

Portner, Paul. 2004. The semantics of imperatives within a theory of clause types. In Proceedings of SALT XIV, Cornell University: CLC Publications. http://semanticsarchive.net/Archive/mJlZGQ4N/PortnerSALTo4.pdf.

Portner, Paul. 2007. Imperatives and modals. Natural Language Semantics 15(4). 351-383. doi:10.1007/s11050-007-9022-y.

Portner, Paul. 2009. Modality Oxford Surverys in Semantics and Pragmatics. Oxford: Oxford University Press.

Potts, Christopher. 2005. The logic of conventional implicatures. Oxford: Oxford University Press.

Quer, Josep. 1998. Mood at the interface. The Hague: Holland Academic Graphics.

Quer, Josep. 2001. Interpreting mood. Probus 13(1). 81-111. doi:10.1515/prbs.13.1.81.

Quer, Josep. 2009. Twists of mood: The distribution and interpretation of indicative and subjunctive. Lingua 119(12). 1779-1787. 
Cross-linguistic variation in modality systems: The role of mood

doi:10.1016/j.lingua.2008.12.003.

Rivero, María. 1975. Referential properties of Spanish noun phrases. Language 51(1). 32-48. doi:10.2307/413149.

Rocci, Andrea. 2007. Epistemic modality and questions in dialogue. the case of Italian interrogative constructions in the subjunctive mood. In L. de Saussure, J. Moeschler \& G. Puska (eds.), Tense, mood and aspect: Theoretical and descriptive issues, 129-153. Amsterdam and New York: Rodopi.

Rullmann, Hotze, Lisa Matthewson \& Henry Davis. 2008. Modals as distributive indefinites. Natural Language Semantics 16(4). 317-357. doi:10.1007/s11050-008-9036-0.

Schwager, Magdalena. 2005. Interpreting imperatives: University of Frankfurt/Main dissertation.

Schwager, Magdalena. 2006. Conditionalized imperatives. In Proceedings of SALT XVI, Cornell University: CLC Publications. http://ecommons.library. cornell.edu/bitstream/1813/7591/1/salt16_schwager_241_258.pdf.

Schwager, Magdalena. 2008. Optimizing the future - imperatives between form and function. Course notes, ESLLI 2008. http://zis.uni-goettingen. de/mschwager/essllio8/ms_schwager_essllio8.pdf.

Stalnaker, Robert. 1974. Pragmatic presuppositions. In Milton Munitz \& Peter Unger (eds.), Semantics and Philosophy, 197-214. New York University Press.

Stalnaker, Robert. 1984. Inquiry. Cambridge, MA: MIT Press.

Tenny, Carol. 2006. Evidentiality, experiencers and the syntax of sentience in Japanese. Journal of East Asian Linguistics 15(3). 245-288. doi:10.1007/s10831-006-0002-x.

Tenny, Carol \& Peggy Speas. 2004. The interaction of clausal syntax, discourse roles and information structure in questions. Paper presented at the Workshop on Syntax, Semantics and Pragmatics of Questions. ESLLI, Université Henri Poincaré, Nancy. http://www.linguist.org/ESSLI-Questions-hd.pdf.

Terrell, Tracy \& Joan Hooper. 1974. A semantically based analysis of mood in Spanish. Hispania 57(3). 484-494. doi:10.2307/339187.

Thoma, Sonja. 2007. The categorical status of independent pronouns in St'át'imcets. Ms., University of British Columbia.

Villalta, Elisabeth. 2009. Mood and gradability: an investigation of the subjunctive mood in Spanish. Linguistics and Philosophy 31(4). 467-522. doi:10.1007/s10988-008-9046-x.

Whitley, Rose (translator), Henry Davis, Lisa Matthewson \& Beveley Frank 
(editors). no date. Teaching St'át'imcets Through Action. Translation of Bertha Segal Cook Teaching English Through Action. Upper St'át'imcets Language, Culture and Education Society.

\author{
Lisa Matthewson \\ UBC Department of Linguistics \\ Totem Field Studios \\ 2613 West Mall \\ Vancouver, BC, V6T 1Z4, Canada \\ lisamatt@interchange.ubc.ca
}

